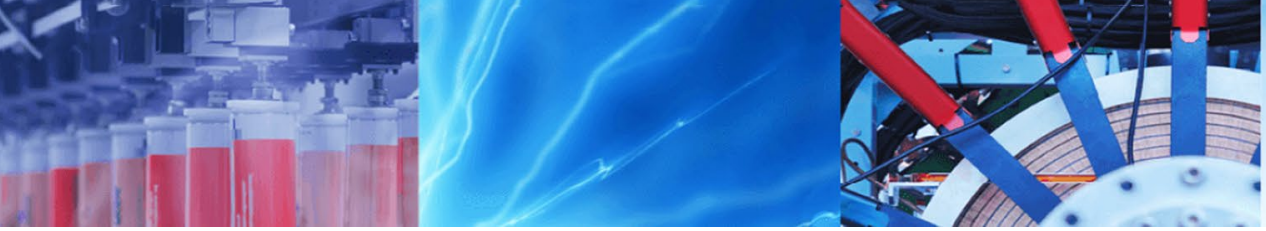

Research Article

\title{
Seasonal variation induced stability of municipal solid waste compost: an enzyme kinetics study
}

\author{
Mansi Rastogi ${ }^{1}$ - Meenakshi Nandal ${ }^{1} \cdot$ Lata Nain $^{2}$
}

(c) Springer Nature Switzerland AG 2019

\begin{abstract}
An investigation was carried out in laboratory to find out the effect of ambient temperature and different treatments on passive bin composting of municipal solid waste (MSW). A potent cellulase degrading inoculum (Bacillus subtilis, $B$. amyloliquefaciens, B. nakamurai and $B$. velezensis) sourced from dumpsite soil and cow dung slurry was used as addon to MSW composters. Treatments were tested during summer $\left(26-45^{\circ} \mathrm{C}\right)$ and winter $\left(5-22^{\circ} \mathrm{C}\right)$ season to profile the physiochemical, enzymatic and microbial changes during 90-day study. In addition, a kinetics model for MSW composting was derived for the rate of organic load degradation deducing the first order kinetics rate $\left(\mathrm{K}_{\mathrm{r}}\right)$, limiting velocity $\left(\mathrm{K}_{\mathrm{m}}\right)$ and dissociation constant $\left(\mathrm{K}_{\mathrm{d}}\right)$. The results of the present investigation revealed that ambient temperature hastened the degradation of organic substrates in case of MSW amended with microbes and cow dung (60 days) as indicated by the achieved maximum kinetics reaction rate, 0.0131 day $^{-1}\left(R^{2}=0.993\right)$ and reduced $C / N$ ratio $(11.6 \%)$. Also, enzymatic profiles; dehydrogenase $\left(170.1 \mu \mathrm{g} \mathrm{TPF} \mathrm{g}{ }^{-1} \mathrm{day}^{-1}\right)$, cellulase $\left(96.1 \mu \mathrm{g}\right.$ glucose $\left.\mathrm{g} \mathrm{dwt}^{-1} \mathrm{~h}^{-1}\right)$ and urease $\left(539.1 \mathrm{gg} \mathrm{NH}_{4}^{+}-\right.$ $\left.\mathrm{Ng} \mathrm{dwt} \mathrm{t}^{-1} \mathrm{~h}^{-1}\right)$ with a high temperature profile $\left(47-63^{\circ} \mathrm{C}\right)$ in the finished summer compost, $\mathrm{Cs}_{4}$ supported the results. Whereas, winter composting could not attain the desired results and produced immature compost even after 90 days. Statistical analysis (proximal cluster analysis, hierarchical cluster analysis and ANOVA) and kinetics study showed that ambient temperature in collaboration with addons significantly influenced the compost maturity.
\end{abstract}

Keywords Municipal solid waste $\cdot$ Composting $\cdot$ Enzyme kinetics $\cdot$ Seasonal variation $\cdot$ Microbial inoculation

\section{Introduction}

Composting attracts the attention of researchers because of its lower operative cost and an environmentally viable solution for waste disposal. The major part of the municipal solid waste generated in India is compostable (50-60\%), offers an opportunity to explore composting as a potential method to manage this waste [1]. Composting is a biotransformation process where the microbial actions generate a stable and pathogen free product used to increase the soil fertility [2]. It includes three phases: (1) an initial decomposition or mesophilic phase $\left(20-45^{\circ} \mathrm{C}\right)$;
(2) a thermophilic or high-temperature phase of intense microbial degradation and (3) a maturation phase that can lasts for several months. During composting, several microbial communities succeed one another depending on the nutritional and environmental conditions prevailing at stages. Microorganisms utilize the available organic sources to supplement their energy requirements and multiplication. In case of MSW, microbiota generates specific hydrolytic enzymes for degrading the organic constituents via composting. The enzyme dehydrogenase indices microbial activity accounting to their oxidative phosphorylation and respiratory mechanisms [3]. While,

Electronic supplementary material The online version of this article (https://doi.org/10.1007/s42452-019-0889-2) contains supplementary material, which is available to authorized users.

Mansi Rastogi, rastogimansi86@gmail.com | 'Department of Environmental Sciences, Maharshi Dayanand University, Rohtak, India. ${ }^{2}$ Division of Microbiology, ICAR-Indian Agricultural Research Institute, New Delhi 110012, India.

SN Applied Sciences (2019) 1:849| https://doi.org/10.1007/s42452-019-0889-2

Received: 28 April 2019 / Accepted: 5 July 2019 / Published online: 11 July 2019 
the enzymes; cellulase (glucose hydrolysis), phosphatase (release phosphate groups), amylase (starch hydrolysis), protease and urease (mineralization of the nitrogenous compounds to generate ammonia) are associated with specific nutrient cycles. However, considering the enormous quantity of waste generated in a developing nation like India with a shrinking land area, natural composting of waste is a time-consuming process [4]. As a solution to the current problem, adding effective microbes (EM) and/or cow dung to waste has been suggested as a useful strategy. These amendments can reduce the time taken for waste degradation and enhanced the compost stability [5-7]. Therefore, monitoring the activity of the microbiota developed within the compost piles is a key for effective waste management through composting. At the same time, the rate of biodegradation and enzymatic parameters reflect the maturity of the compost [8].

For efficient composting, an optimum moisture content (40-60\%), C/N ratio (25-30), aeration rate $(0.005-0.300 \mathrm{~L}$ air $\mathrm{kg}^{-1}$ ) and appropriate bulking agents (to facilitate better air circulation) are some important parameters. Apart from the above-mentioned parameters, the temperature attained in the compost mass significantly affects the rate of bio-oxidation in compost piles. During composting the ambient temperature influences the temperature conserved within the waste heap thereby achieving better humification of waste [9]. Subsequently, in summer season due to a higher ambient temperature, more heat is developed within the waste pile that intensifies the microbial activity and waste decomposition [10]. On the other hand, during winter, less heat is conserved, that prevents the pile from attaining an optimum temperature for composting. The lack of optimum temperatures might result in generation of an immature and unhealthy compost. Therefore, we need to determine the effect of seasonal ambient temperature on the rapid composting of MSW.

Kinetics modelling is a vital tool to design and operate composting facilities. This fosters the need to understand compost kinetics complied with the market demands and environmental regulations [11]. Modelling of compost kinetics is extensively studied through substrate degradation models. The substrate degradation is studied along time period with substrate concentration as independent variable. Previous investigations studied the effect of seasonal temperature on composting, no past attempts for detailed assessment of the kinetics between microbial and enzymatic dynamics with an added commixture (EM and cow dung slurry) to MSW are known. The present study monitored the effect of seasonal temperature and additives on the compost kinetics during an aerobic passive bin MSW composting. The effect of seasonal temperature (ambient and compost pile) on the prevailing microbial diversity (innate, EM and cow dung induced), process speed and product quality for different treatment mixtures was explored. Compost kinetics for degradation of MSW was assessed and validated by multivariate statistical analysis. In addition, some fundamental chemical equations were derived to assess the order of MSW degradation rate. The research findings rebounded the significance of compost kinetics for MSW degradation. The study also accounted the role of ambient temperature with additives on waste degradation rate during composting and added information to the existing literature.

\section{Materials and methods}

\subsection{Compost sampling and analytical methods}

Collection and processing of samples: The MSW samples (five) comprising of degradable and non-degradable fractions was procured from an open dumpsite in Sunaria village at Rohtak city in Haryana (100 13'58.08" North, 770 31'02.40" East, elevation 1929 m) (Fig. 1). The samples were air dried and segregated for the organic fractions followed by oven drying at $60^{\circ} \mathrm{C}$ for $24 \mathrm{~h}$. The materials were then shredded to a size of $1.0-1.5 \mathrm{~mm}$ for further processing. The initial physicochemical analysis of MSW was done as per standard protocols.

Experimental setup: Passive aeration composting experiment was done in plastic bins $(1.5 \mathrm{~m} \times 0.6 \mathrm{~m})$ with 40 circular holes (diameter- $50 \mathrm{~mm}$ ) and perforated PVC pipe $(38 \mathrm{~mm}$ ) to supply sufficient air supply ( $8 \mathrm{~h}$ in a day at rate of $1.5 \mathrm{~L} / \mathrm{min} / \mathrm{kg} / \mathrm{OM}$ ) to the feedstock material. Treatment bins were packed with $15 \mathrm{~kg}$ shredded and dried MSW after removing plastic, glass and metal (Fig. 2). The bulking agent sawdust, green and dry brown constituents were added to all the treatment bins (1:7:6). The initial feedstock mass for compost mixture was computed as given in Eq. (1) [12]. A mixed consortium (Bacillus subtilis, B. tequilensis, B. venezuelans and B. nakamurai) isolated from dumpsite soil was sprayed on the feedstock material (bacterial load $-5 \mathrm{ml}^{2} 2 \times 10^{9} \mathrm{CFU} \mathrm{ml}{ }^{-1}$ ) to treatment bin $\mathrm{Cs}_{2}$ and $\mathrm{Cs}_{4}$. One $\mathrm{kg}$ fresh cow dung was prepared into a slurry with distill water $(1: 50, \mathrm{w} / \mathrm{v})$ and added to bin $\mathrm{Cs}_{3}$ and $\mathrm{Cs}_{4}$. Eight treatments were maintained as compiled in Table 1. All the treatments were maintained with a moisture content of $55 \%$, which is inclusive of the water used while making dilutions for cowdung and inoculum. The experiential set up was kept in screen house facility with an average ambient temperature $\left(30-35^{\circ} \mathrm{C}\right.$ in summer and $10-15{ }^{\circ} \mathrm{C}$ in winter) and relative humidity as $60 \%$. A leachate collection facility was also provided in the bottom of the compost bins. The compost mixture was regularly turned to maintain the required temperature and aeration. 

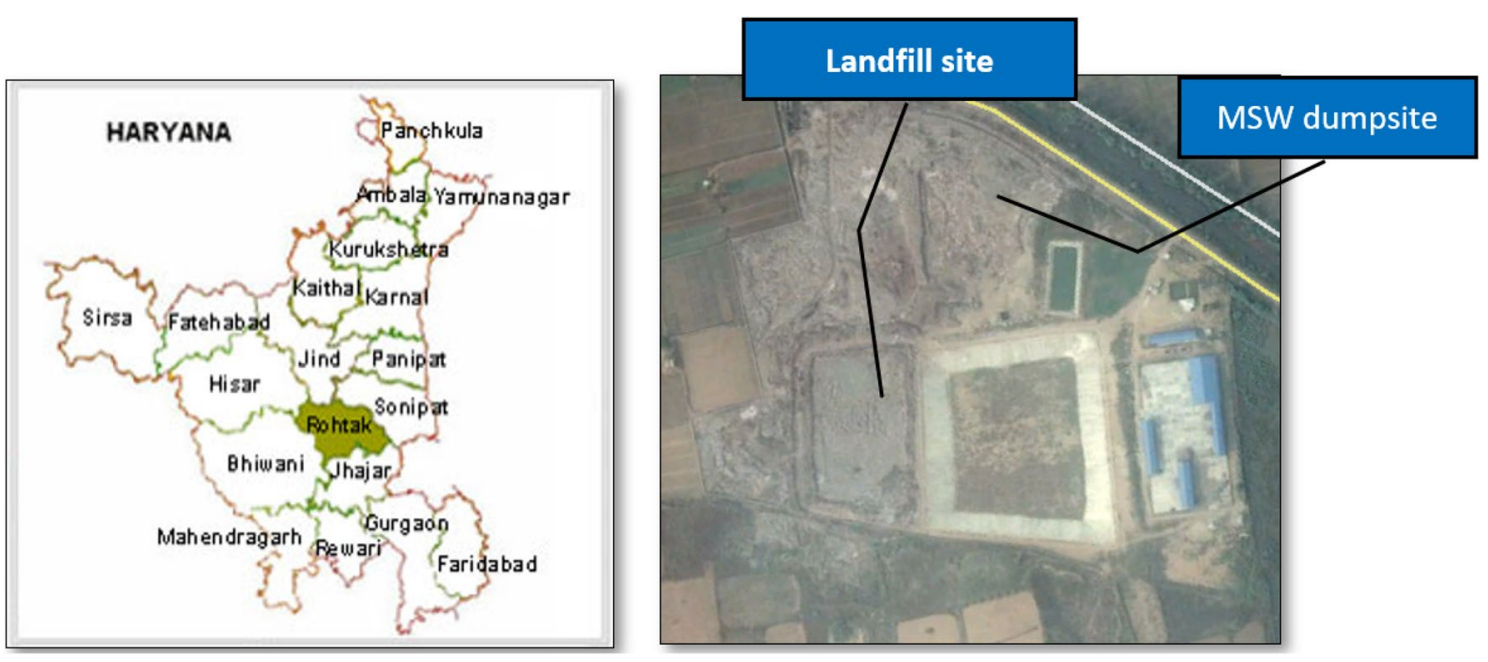

Fig. 1 Study area (landfill site at Sunaria village, Rohtak)
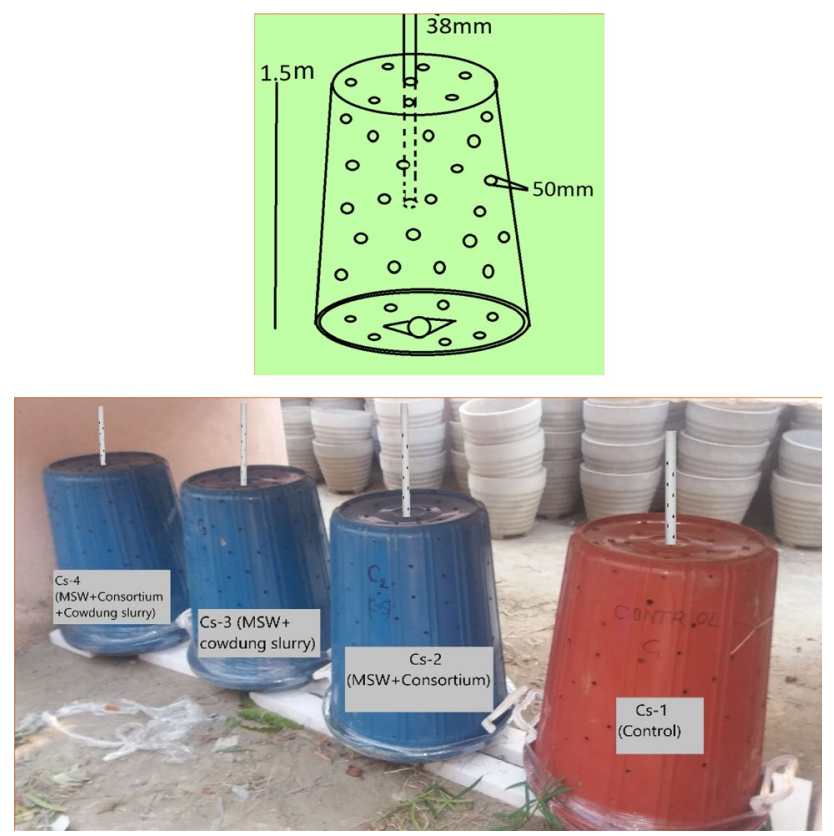

Fig. 2 Passive aerobic bin composter

$\mathrm{G}=\frac{\mathrm{M}_{1} \times \mathrm{Q}_{1}+\mathrm{M}_{2} \times \mathrm{Q}_{2}+\mathrm{M}_{3} \times \mathrm{Q}_{3}+\mathrm{M}_{4} \times \mathrm{Q}_{4}}{\mathrm{Q}_{1}+\mathrm{Q}_{2}+\mathrm{Q}_{3}+\mathrm{Q}_{4}}$

where $\mathrm{Q}_{\mathrm{n}}$ is the mass of material $\mathrm{n}$ (wet weight basis); $\mathrm{G}$ the moisture goal (\%); $M_{n}$ the moisture content (\%) of material $n$.

Physiochemical analysis: Grab sampling (50 gm) was done from three different depths $(5 \mathrm{~cm}, 10 \mathrm{~cm}$ and $15 \mathrm{~cm}$ ) of the composting pile at regular intervals after 0,15 , $30,45,60$ and 90 days. These samples were then mixed thoroughly to make a homogenized sample and stored at $4{ }^{\circ} \mathrm{C}$ for stability. The physical analysis of compost (wet sample) was done within $24-48 \mathrm{~h}$ and for chemical analysis the compost samples were air dried $\left(25^{\circ} \mathrm{C}\right.$ for 2 days). Changes in temperature was monitored daily by using a digital thermometer, kept permanently in middle of the treatment bins. $\mathrm{pH}$ of the compost was determined by digital $\mathrm{pH}$ meter with a glass electrode $(1: 5(\mathrm{w} / \mathrm{v})$ compost: water ratio)). The total organic carbon of the compost was estimated through Rapid dichromate oxidation process [13] and total nitrogen (TN) by Micro Kjeldahl method [14]. For calculation of C:N ratio, percent of total organic carbon was divided by percent of total nitrogen. Enumeration of microbial load was done by spread plate counting method [15] by counting the colony forming units (CFU) per dry weight of composts (Eq. 2). For aerobic bacteria and fungi, $1 \mathrm{ml}$ of homogenate was placed on nutrient agar plates and sabouraud dextrose agar plates in triplicates.

$\log _{10}$ colony count $i$

$$
=\log 10 \frac{(\text { Number of Colony } \times \text { Dilution factor } \times 100)}{\text { Moisture content }}
$$

CFU/g dry sample (Eq. 2)

In study, the enzyme activity was evaluated at each time-point on freshly grounded and sieved $(<2 \mathrm{~mm})$ compost samples $(1.0 \mathrm{~g})$. The dehydrogenase activity was assayed by employing TTC (triphenyl tetrazolium chloride) with methanol as substrate, incubated at $30^{\circ} \mathrm{C}$ for $24 \mathrm{~h}$ and represented as $\mu \mathrm{g} \operatorname{TPF~}^{-1}$ day $^{-1}$ [16]. The cellulase activity was expressed in filter paper unit (FPU) by using carboxy methyl cellulose as substrate, dissolved in $0.1 \mathrm{M}$ citrate buffer (pH 5.0) [17]. For measuring amylase activity, starch 
Table 1 Waste proportion with ratio of mixtures and initial physico-chemical characteristics

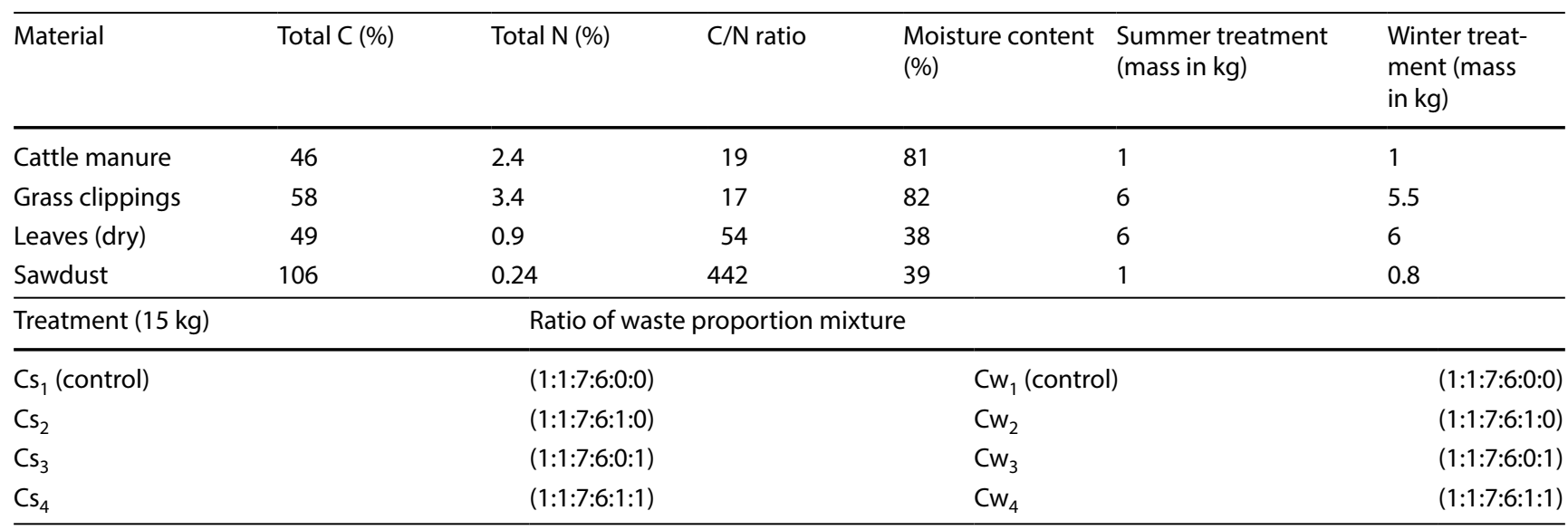

Constituents: MSW, sawdust, brown matter, grass clippings, microbial consortia and cowdung

Table 2 Physico-chemical characteristics (initial) of raw MSW for summer and winter season

\begin{tabular}{lrr}
\hline Parameter & Summer treatment & Winter treatment \\
\hline $\mathrm{pH}$ & $8.06 \pm 0.005$ & $8.59 \pm 0.005$ \\
Total moisture content (\%) & $78 \pm 0.002$ & $61 \pm 0.002$ \\
Total Nitrogen (\%) & $0.55 \pm 0.003$ & $0.49 \pm 0.015$ \\
Total organic carbon (\%) & $33.5 \pm 0.019$ & $31.8 \pm 0.005$ \\
C/N ratio & $61.4 \pm 0.001$ & $52.9 \pm 0.014$ \\
\hline
\end{tabular}

$(\mathrm{n}=3 ;$ Mean $\pm S D)$

was dissolved in $0.1 \mathrm{M}$ acetate buffer $(\mathrm{pH} 4.7)$ and the amount of maltose released was estimated by DNSA method [18]. Protease activity was estimated using Tris $\mathrm{HCl}$ as buffer ( $\mathrm{pH}$ 8.1) and denaturalized (heated) casein as substrate following the Folin-ciocalteau method [19]. The urease activity was quantified according to Weatherburn [20] by determining the $\mathrm{NH}_{4}^{+}$ion formed in supernatant. The Alkaline and acidic phosphatase activity was assayed at $\mathrm{pH} 9.0$ and 5.0 with glycine $(0.1 \mathrm{M})$ /acetate $(0.1 \mathrm{M})$ buffer ensuing the Tabatabai and Bremner method [21]. All the enzymatic activities were expressed as $\mu \mathrm{g}$ product released $\mathrm{g}^{-1} \mathrm{DM} \mathrm{h}^{-1}$ [22].

Statistical analyzes were done using SPSS-23.0 statistical package on averages of $n=3 \pm$ standard deviations. Statistical analysis of multiple correlations between physicchemical parameters and organic matter degradation was made using a principal component analysis (PCA), Hierarchical Cluster Analysis (HCA) and a correlation matrix.

\section{Results and discussion}

The physio-chemical analysis of the initial raw MSW used for the investigation has been detailed in Table 2. The changes observed during the passive bin composting of
MSW within different waste treatment mixtures and the seasonal temperature variation pictured a positive effect on simulation of the composting process.

In the present investigation, Temperature (Fig. 3) showed an increase during early phase of composting for all the MSW treatments (both season), from the ambient ( 0 day) to the thermophilic stage (45th day) followed by a reduction in later stages of composting (90th day). However, the rise in temperature in case of summer composting (inoculated) proceeded much faster than winter composting. The temperature-time pattern of the MSW composting pile was majorly in the thermophilic range for the summer treatment (Cs) with highest temperature observed in treatment $\mathrm{Cs}_{4}\left(63^{\circ} \mathrm{C}\right)$ by 45 th day followed by treatment $\mathrm{Cs}_{3}$, and $\mathrm{Cs}_{2}\left(49\right.$ and $46^{\circ} \mathrm{C}$ ). Whereas, the winter treatments recorded an increase $\left(39^{\circ} \mathrm{C}\right)$ in temperature only during the thermophilic (45th day) period of composting. Thermophilic microbes, which accelerated oxidative reactions, are likely responsible for the released heat during summer composting showing an influence of inoculum and ambient temperature [24]. The ambient temperature and proper aeration might have influenced microbial activity that resulted in higher organic matter mineralization and better compost stability. By all accounts, it confirmed that the summer compost has achieved a good sanitation degree. Whereas, for winter treatment, an unexpected increase $\left(25 ; 28^{\circ} \mathrm{C}\right)$ was seen around day 90 (at maturation) in $\mathrm{CW}_{3}$ and $\mathrm{CW}_{4}$ treatment suggesting incomplete decomposition, resulting in an immature compost.

In study, pH typically varied for both summer and winter treatments (Fig. 4) exhibiting an increased $\mathrm{pH}$ with a maximum $\mathrm{pH}$ recorded on 90th day (end stage) of experiment. An initial acidic pH (5.31-5.9) was exhibited by all treatments (both season) up to 15th day with a subsequent increase during the thermophilic stage of 
Fig. 3 Changes in temperature in MSW treatment piles during 90 days of composting in summer and winter season
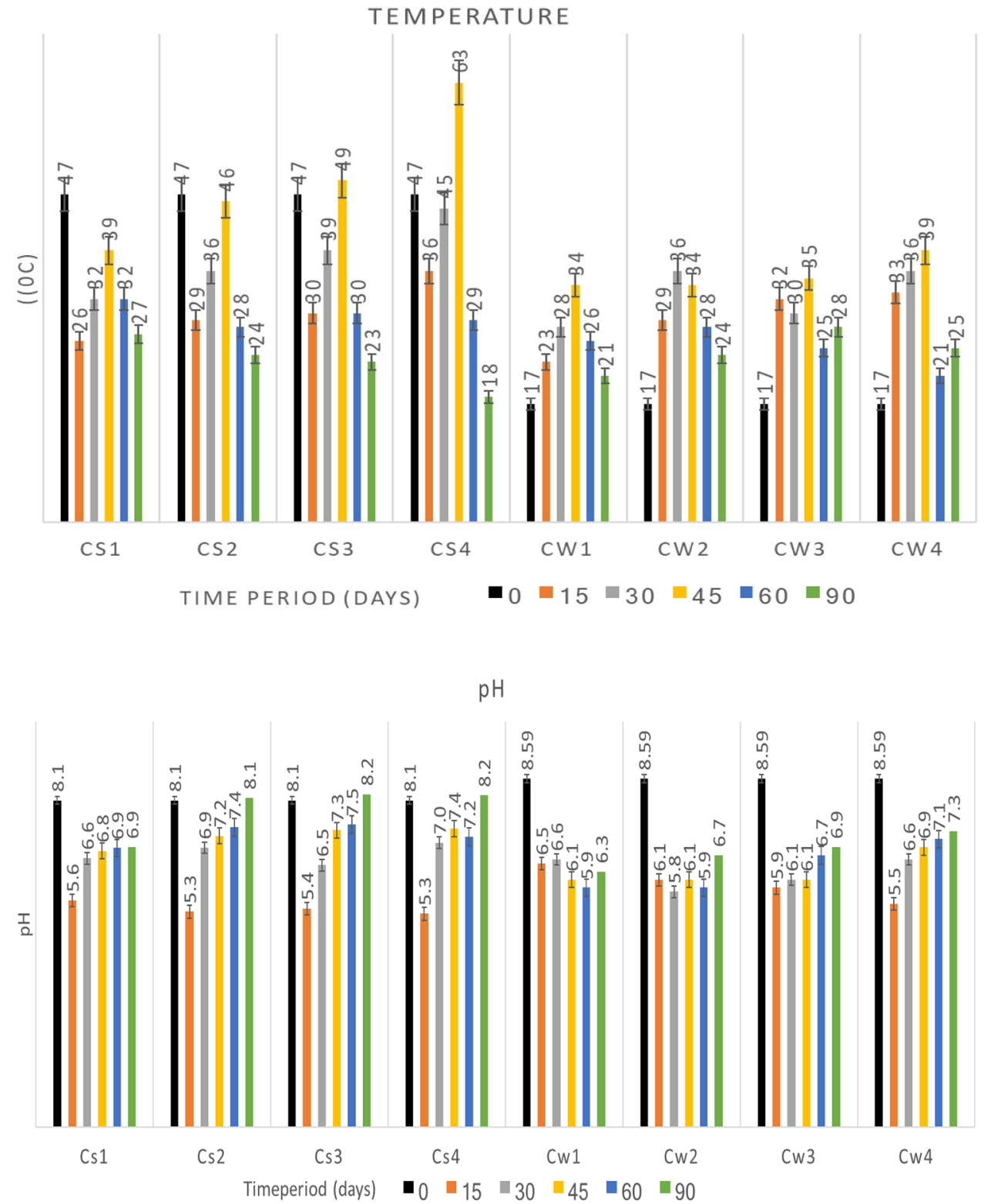

Fig. 4 Changes in $\mathrm{pH}$ in MSW treatment piles during 90 days of composting in summer and winter season composting (30-45 day). It indicates breakdown of protein molecules in the organic waste with release of ammonia, which was in agreement with Li et al. [23]. However, the $\mathrm{pH}$ turned slightly alkaline $\left(\mathrm{Cs}_{2}-8.1, \mathrm{Cs}_{3}-8.2\right.$ and $\left.\mathrm{Cs}_{4}-8.2\right)$ in case of all summer treatments except $\mathrm{Cs}_{1}(\mathrm{pH}-6.9)$ at the end phase of decomposition, i.e. 90th day. This alkaline $\mathrm{pH}$ might be because of the faster synthesis of phenolic compounds during degradation process. This is suggestive of a faster degradation of organic fractions in summer treatments with respect to composting time period. Whereas, in the winter treatments $\mathrm{pH}$ showed a decreased $\mathrm{pH}$ stability with increasing days of MSW composting, indicating slower degradation and higher production of organic acids.
Figure $5 \mathrm{a}, \mathrm{b}$, illustrates the logarithm changes in the microbial biomass during passive composting of MSW. It was found that the microbial biomass for summer treatment (inoculated/non-inoculated) increased notably with time ( 45 days) followed by marginal decrease. Conversely, in case of winter treatment the microbial biomass showed a marginal decline in values at the end of experimental period. Amon the various treatments, summer treatment $\mathrm{Cs}_{4}$ reported maximum bacterial biomass $\left(19.80 \times 10^{7} \mathrm{CFU} / \mathrm{g}\right)$ on 30th day of composting followed by $\mathrm{Cs}_{3}\left(13.50 \times 10^{7} \mathrm{CFU} / \mathrm{g}\right)$ and $\mathrm{Cs}_{2}\left(10.30 \times 10^{7} \mathrm{CFU} / \mathrm{g}\right)$ on 45th day. This is assessed to prevalence of dominant actinomycetes and thermophilic bacteria (mainly Bacillus species) and initial addons (bacillus culture and cowdung slurry) that increased readily available carbon substrates 
Fig. 5 Changes in microbial diversity $\mathbf{a}$ bacteria and $\mathbf{b}$ fungi in MSW treatment piles during 90 days of composting in summer and winter season

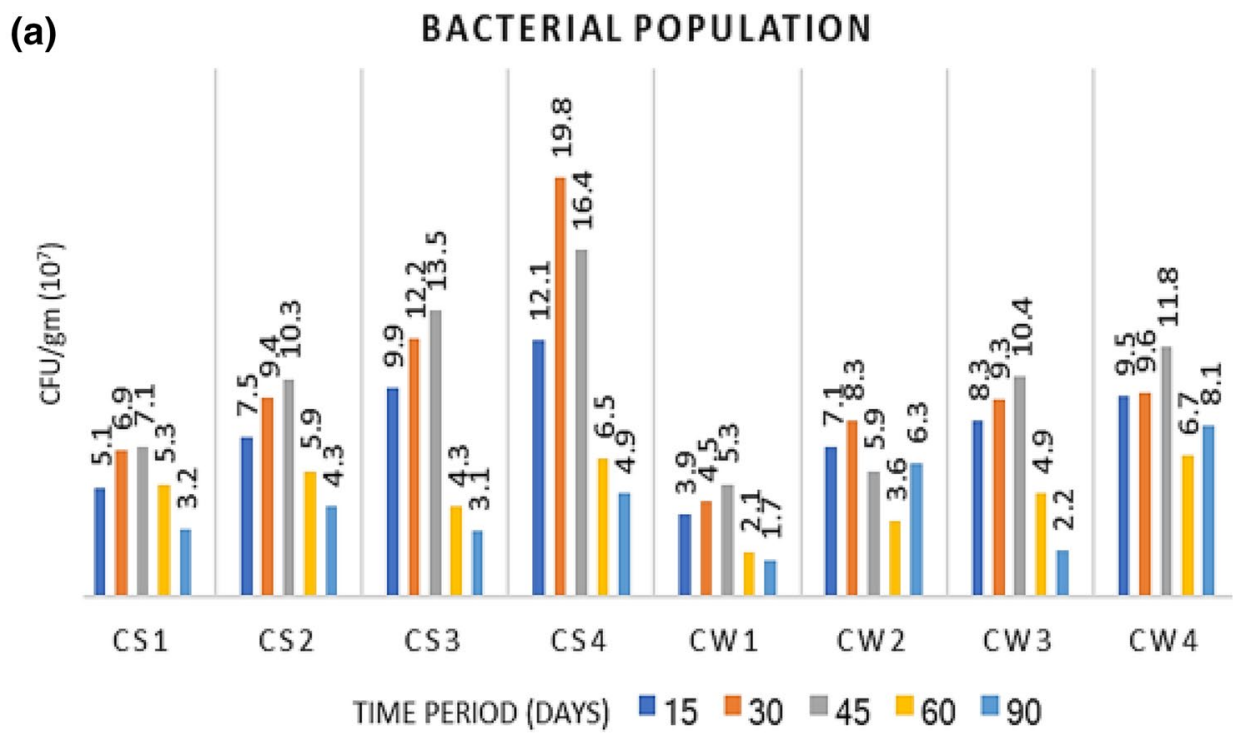

(b)

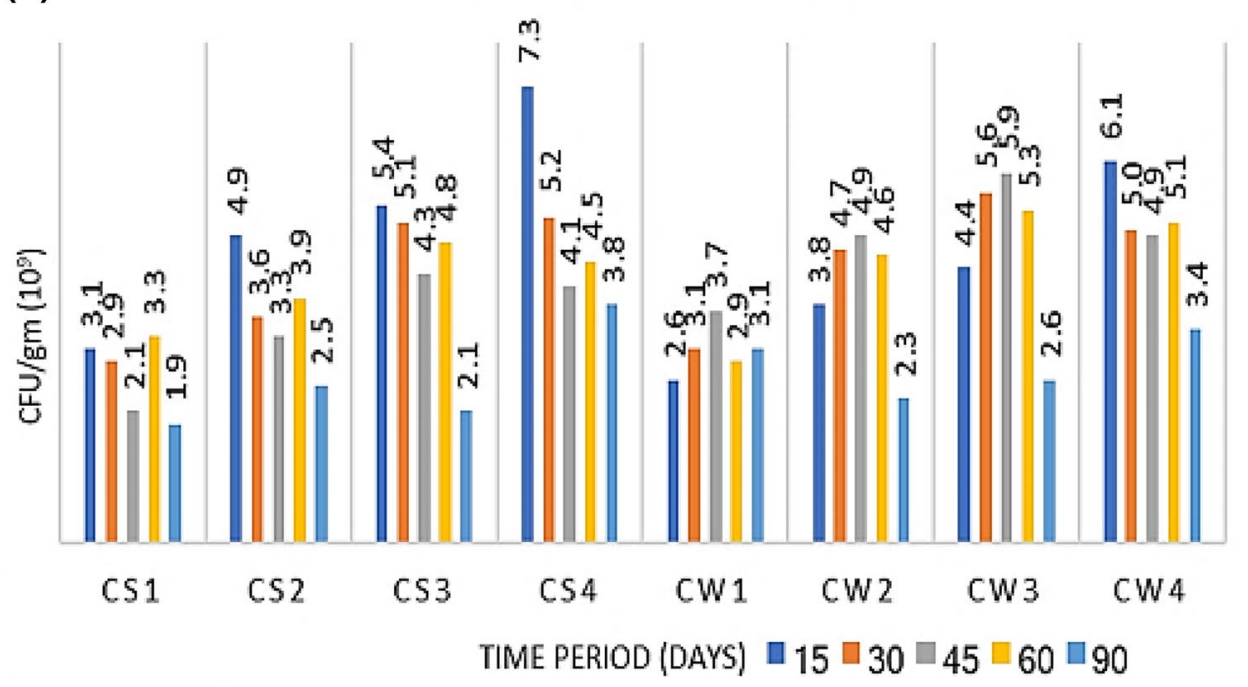

resulting in higher microbial growth. Whereas, for winter treatments, treatments $\mathrm{CW}_{1}\left(1.7 \times 10^{7} \mathrm{CFU} / \mathrm{g}\right)$ and $\mathrm{CW}_{3}$ $\left(2.2 \times 10^{7} \mathrm{CFU} / \mathrm{g}\right)$ registered the lowest bacterial count on last day (90th) of experiment. As expected, at maturation stage a decreasing bacterial population followed the trend $\mathrm{Cs}>\mathrm{Cw}$, attributed to the moisture loss as maturity proceeds in the curing stage [25]. Comparing all the treatments, the fungal population was higher for summer treatments in initial stage of composting, probably because of early maturation and curing of compost. Whereas, winter treatments showed increased fungal biomass at later stages of composting indicating slower humification and an immature compost.

A perusal of results for both seasons revealed that total organic carbon concentration (Fig. 6a) was inversely proportional to time [26]. It was found that with time, the maximum reduction in TOC from $33.5 \%$ ( 0 day) to $23.10 \%$ in treatment $\mathrm{Cs}_{4}$, followed by $\mathrm{Cs}_{3}(22.10 \%), \mathrm{Cs}_{2}(21.80 \%)$, and control (21.70\%) for summer treatments (90th day), considerably more stabilized than winter set. Higher reduction in treatment $\mathrm{Cs}_{4}$ was ascribed to presence of readily available nutrients due to cow dung slurry addition and inoculated culture, sourcing efficient microbial degradation and established higher temperature. This is in concordant with results obtained by Cabrera et al. [27] suggesting that the decomposition process had ceased and the compost attained maturity by 60th day in case of summer treatments. However, in case of winter treatments the desired results in for TOC could not be attained, possibly due to insufficient rise in temperature and underdeveloped microbial growth.

The experimental observations revealed that total nitrogen content (Fig. 6b) was low initially ( 0 day) in case of all the eight treatments $\left(\mathrm{Cs}_{1}-\mathrm{Cs}_{4}\right.$ to $\left.\mathrm{Cw}_{1}-\mathrm{Cw}_{4}\right)$ 
Fig. 6 Changes in a total organic carbon, $\mathbf{b}$ total nitrogen, $\mathrm{c} C / \mathrm{N}$ ratio in MSW treatment piles during 90 days of composting in summer and winter season (a)

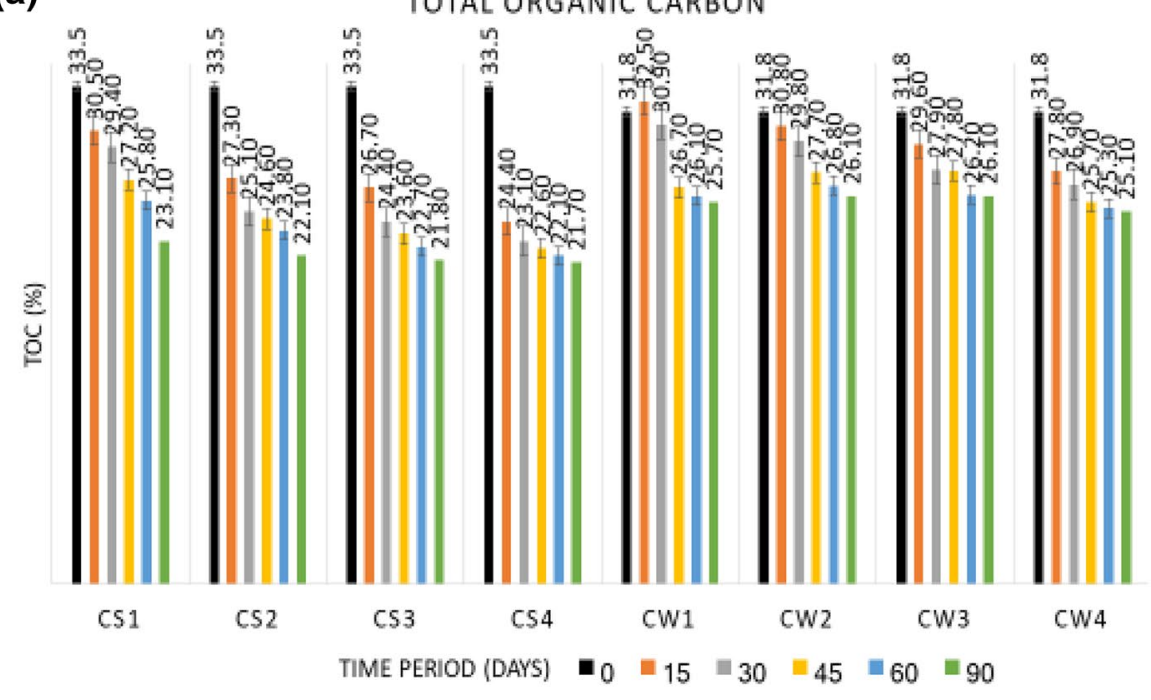

(b)

TOTAL NITROGEN

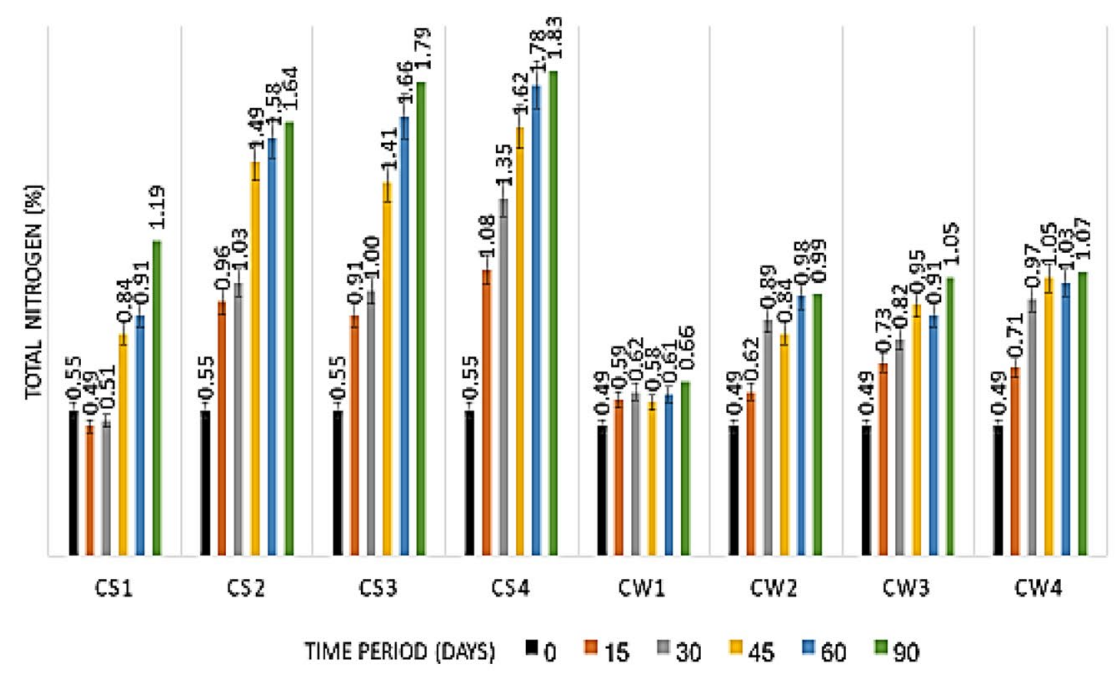

(c)

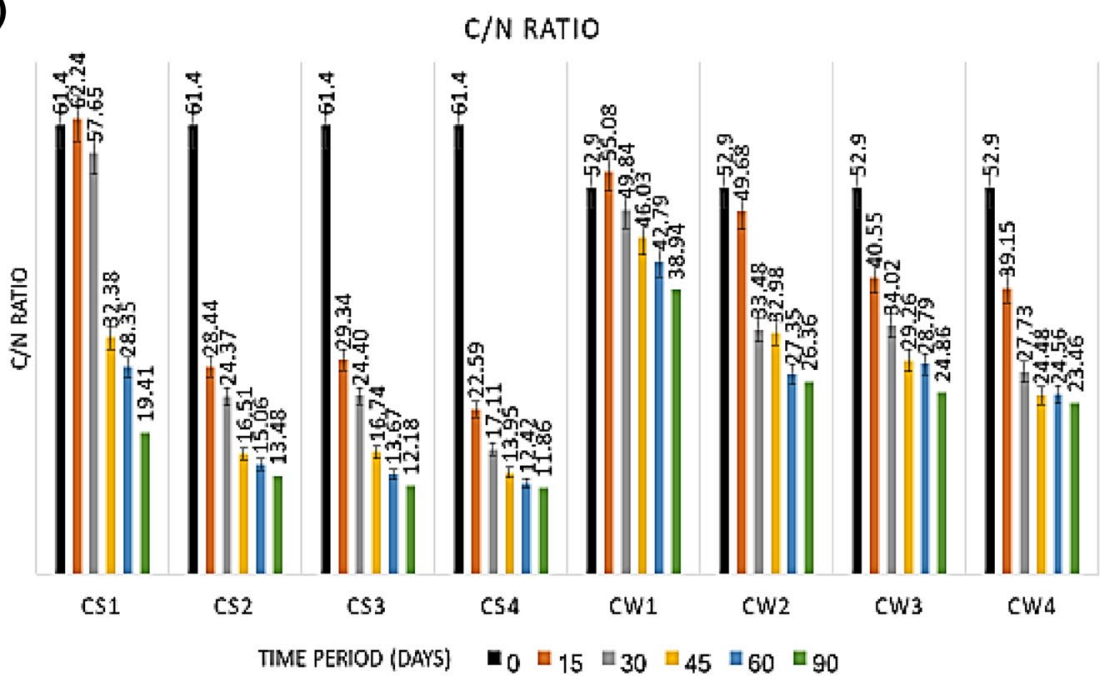


and increased gradually for both seasons with composting time. As the organic matter becomes more stabilized with time, the nitrogen mineralization accelerated during MSW composting [28]. This documented increase in nitrogen content was higher for summer treatment $\mathrm{Cs}_{4}$ (1.83\%) followed by $\mathrm{Cs}_{2}(1.79 \%)$ and $\mathrm{Cs}_{1}(1.64 \%)$ than control $\left(\mathrm{Cs}_{1}\right)$ on 90 th day, respectively. Whereas for winter season, lower concentration of total nitrogen was reported on all observation days, ascribed to poor mineralization process during winter composting.

Data for the effect of seasonal variation and addons on $\mathrm{C} / \mathrm{N}$ ratio during MSW composting have been shown in Fig. $6 \mathrm{c}$. The results showed that $\mathrm{C} / \mathrm{N}$ ratio for summer season, specifically microbial and cowdung facilitated treatment bin was better than all the other treatments. Within 90 days, the $\mathrm{C} / \mathrm{N}$ ratio reduced from 61.4 ( 0 day) to 11.86 for treatment $\mathrm{Cs}_{4}$ followed by $\mathrm{Cs}_{3}, \mathrm{Cs}_{2}$ and control $\mathrm{Cs}_{1}(12.18,13.48$ and19.41) for summer season. The obtained results are indicative of an acceptable maturity (between 10 and 15), as suggested by Zaccheo et al. [30]. Whereas, winter treatments the reduction was lower for $\mathrm{Cw}_{4} . \mathrm{Cw}_{3}, \mathrm{CW}_{2}$ and control $\mathrm{Cw}_{1}(23.86,24.86,26.38$, 38.94), implied to higher evolution of carbon dioxide due to carbon transformation during summer [29]. Moreover, the drop-in moisture content during winter treatment might have slowed down the metabolic reactions of microbes resulting in a higher $\mathrm{C} / \mathrm{N}$ ratio. Another interesting observation was that though highest reduction in $\mathrm{C} / \mathrm{N}$ ratio for MSW was observed on the last day of experiment, an early reduction (30 day) could be observed in inoculated summer treatments. It is suggested that for an effective composting with reduced time period, the initial acclimatizes should essentially target the early stages of composting activity [36]. The result is analogous to the reporting's by Edris et al. [30] and Sudarshan et al. [31], where summer compost stabilized faster than winter indicating effectiveness of the facilitated treatments for rapid degradation of organic matter.

The monitoring of enzymatic activity is essential for gaining an insight to microbial transformations taking place during composting [32]. The enzymatic activity (Fig. 7a-g) showed an overall increase for all the treatments (summer and winter season) between 15 and 30 days of composting. Among the treatments, dehydrogenase activity was observed to be higher and statistically significant in treatment $\mathrm{Cs}_{4}\left(170.1 \mu \mathrm{g} \mathrm{TPF} \mathrm{g}{ }^{-1} \mathrm{dwt}\right.$ day $\left.^{-1}\right)$ followed by $\mathrm{Cw}_{4}\left(129.1 \mu \mathrm{g}\right.$ TPF g ${ }^{-1}$ dwt day $\left.^{-1}\right)$ in the 2 nd week of composting, ascribed to enhanced enzyme action in the treatments by booster addons (microbes and cow dung slurry). The added mixture of bacillus inoculum and cow dung might have stimulated the enzymatic synthesis due to surplus availability of substrates. However, at later stages the dehydrogenase activity drastically declined for both summer and winter treatments. From previous study, this decline is related to decrease in $\mathrm{pH}$, organic substrate concentration and increased release of phytotoxic compounds when mineralization is achieved during composting [33], which was in agreement with our results.

Data for Urease activity (Fig. 7b) shows a sharp increase (15th day) for both seasons at beginning of composting, followed by a sudden decline. Among various treatments, the activity of urease was higher (observed on 15th day) for summer treatment $\mathrm{Cs}_{4}\left(539.1 \mu \mathrm{g} \mathrm{NH_{4 }}{ }^{+}-\mathrm{N} / \mathrm{g} \mathrm{dwt} \mathrm{h}\right)$, followed by winter treatment $\mathrm{Cw}_{4}\left(383.4 \mathrm{NH}_{4}{ }^{+}-\mathrm{N} / \mathrm{g}\right.$ dwt h) during passive composting. It is reasonable here to hypothesize an increased available carbon and enzyme production elevating the humic substances production by the facilitated mixture of microbes and cow dung slurry [34]. It was observed that urease activity for the treatment $\mathrm{Cs}_{3}\left(377.8 \mu \mathrm{g} \mathrm{NH}_{4}{ }^{+}-\mathrm{N} / \mathrm{g} \mathrm{dwt} \mathrm{h}\right)$ was found to be lower than $\mathrm{Cs}_{2}\left(298.1 \mu \mathrm{g} \mathrm{NH}_{4}{ }^{+}-\mathrm{N} / \mathrm{g}\right.$ dwt h$)$, induced by the competition and interference of the diverse microbes present in the cow dung slurry [5]. More interestingly, at later stages of composting a lower reduction rate was observed for the urease activity for both seasons $\left(C_{s}-6\right.$ th week and $C_{w}-8$ th week), attributed to the process of "resynthesis" [34]. The process occurs because of a direct response of certain bacterial species to the constitutive ureases or to urea as a substrate. However, for winter season, the observed final urease activity was rather low than for summer treatments at last days of experiment (90 day).

The results for Cellulase activity (Fig. 7c) during MSW composting showed an increase in similarity with previous cases (amylase and urease), up to 15th day of passive composting. This was followed by a sharp decline in cellulase activity during later stages of MSW composting in the order; $\mathrm{Cs}_{4}>\mathrm{Cs}_{1}>\mathrm{Cs}_{2}>\mathrm{Cw}_{4}>\mathrm{Cs}_{3}>\mathrm{Cw}_{1}>\mathrm{Cw}_{2}>\mathrm{Cw}_{1}$, indicating the decreased microbiota and the substrate availability. Contrasting to this, an increase in cellulase activity was noticed in (controls) $\mathrm{Cs}_{1}$ and $\mathrm{Cw}_{1}$ till 6 th week $(35.2 \mu \mathrm{g}$ glucose $\left.\mathrm{g} \mathrm{day}^{-1} \mathrm{~h}^{-1}\right)$ and 8 th week ( $14.2 \mu \mathrm{g}$ glucose/g dwt $\mathrm{h}$ ) indicating that cellulose was available as substrate till last due to slower degradation [32]. A maximum of cellulose hydrolysis occurred in summer treatment $\mathrm{Cs}_{4}(96.1 \mu \mathrm{g}$ glucose $/ \mathrm{g} \mathrm{dwt} \mathrm{h)} \mathrm{within} 15$ days that declined to $14.5 \mu \mathrm{g}$ glucose/g dwt $h$ at the end of composting (90th day). Whereas, in case of winter the registered cellulose activity was comparatively lower than summer indicating slower cellulose degradation.

(Figure 7d), explains the amylase activity increased for both the seasons during MSW composting. A perusal of results showed an increase in amylase activity up to 4th week (except in controls $\mathrm{Cs}_{1}$ and $\mathrm{Cw}_{1}$ ), superseded by a steady decline, owing to the mechanism of starch hydrolysis during MSW composting. Amylase activity was found to 
(a)

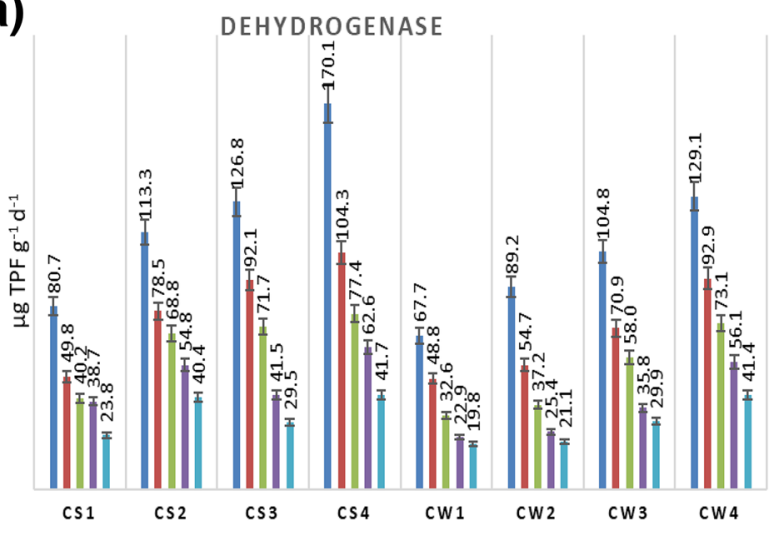

(c)

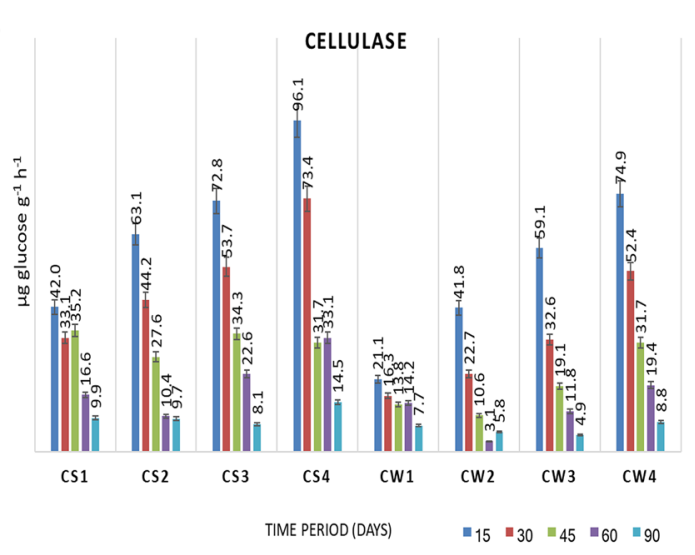

(e)

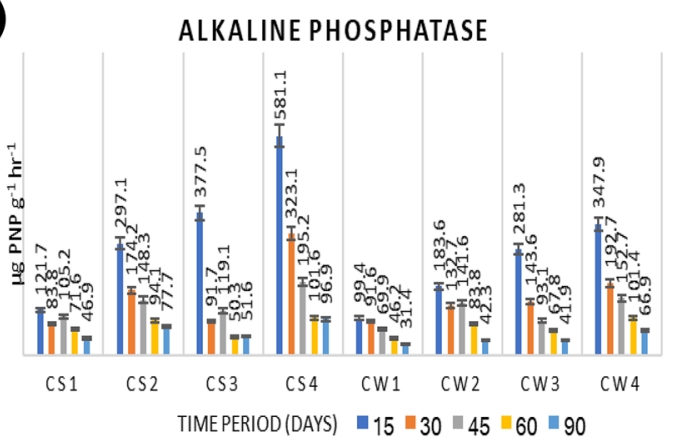

(b)

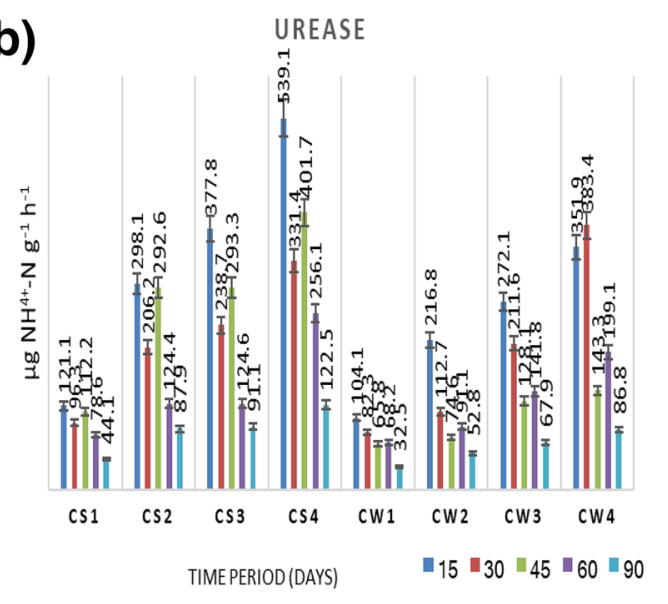

(d)

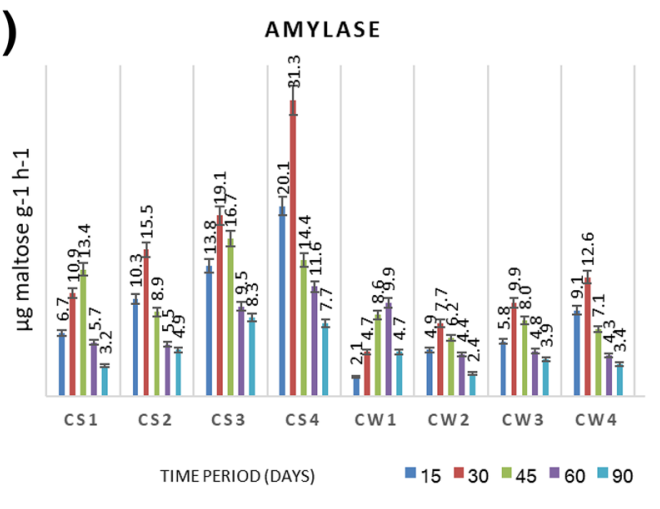

(f)

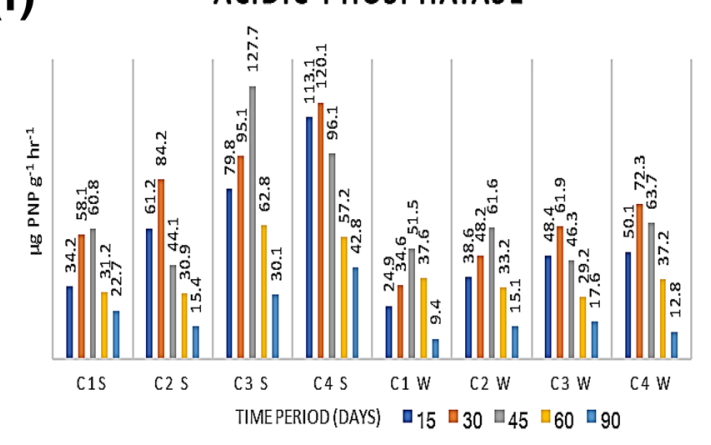

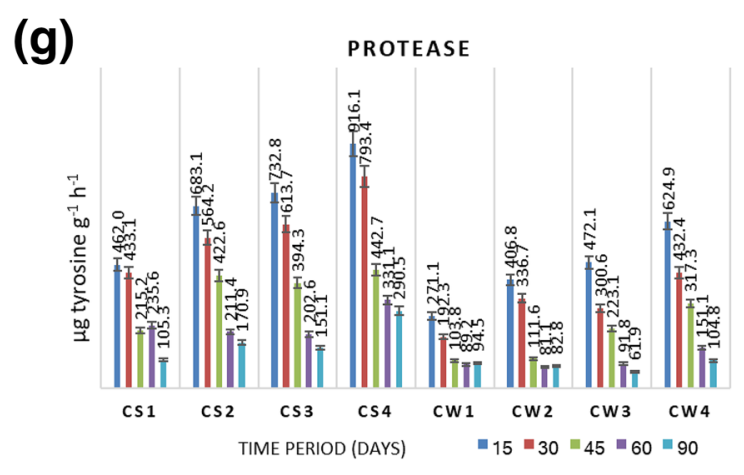

Fig. 7 Changes in enzymatic activity a Dehydrogenase, $\mathbf{b}$ urease, $\mathbf{c}$ cellulase, $\mathbf{d}$ amylase, $\mathbf{e}$ alkaline phosphatase, $\mathbf{f}$ acidic phosphatase, $\mathbf{g}$ protease in MSW treatment piles during 90 days of composting in summer and winter season 
be highest in $\mathrm{Cs}_{4}$ treatment (30th day), at $20.1 \mu \mathrm{g} / \mathrm{maltose}$, that decreased rapidly at later stages at $7.7 \mu \mathrm{g} / \mathrm{maltose}$ (90th day). On the contrary, for winter treatments $\mathrm{Cw}_{4}$ $(12.6 \mu \mathrm{g} / \mathrm{maltose})$ showed higher amylase activity up to day 30 of composting. This indicated that amylase activity was highest for the treatment where inoculum and cowdung slurry was facilitated. However, early degradation of starch in summer treatments could have ascribed as a result of ambient temperature influenced increased microbial biomass during initial stage of composting. Perhaps, in agreement with Castaldi et al. [35] maximum degradation of starch took place during the initial 15-30 days of composting due to presence of abundant organic matter.

Alkaline phosphatase is synthesized by microorganisms only (not from plant residues) and therefore, is a relevant enzyme for the characterization of efficacy of the composting process [36]. In the experiment, a higher activity for alkaline phosphatases (Fig. 7e) was observed in comparison to acidic phosphatase activity (Fig. 7f) for both seasons $\left(C_{s}\right.$ and $\left.C_{w}\right)$, respectively. This increased alkaline phosphatase activity during composting is attributed to more active alkaline phosphatases at neutral $\mathrm{pH}$ range of composts [37]. The alkaline and acidic phosphatase activity was highest for the summer treatment $\mathrm{Cs}_{4}(581.1 \mu \mathrm{g}$ PNP $\mathrm{g}^{-1} \mathrm{~h}^{-1}$ and $42.8 \mu \mathrm{g} \mathrm{PNP} \mathrm{g}^{-1} \mathrm{~h}^{-1}$ ), mainly indorsed to the combined effect of additives (EM and cow dung), followed by $\mathrm{Cs}_{3}, \mathrm{Cs}_{2}$ and $\mathrm{Cs}_{1}$ after day 15 of composting. Whereas, for winter treatment the recorded phosphatase activity was comparatively lower in the order; $\mathrm{CW}_{4}-347.4>\mathrm{CW}_{3}$ 281.3 $>\mathrm{CW}_{2}-183.6>\mathrm{CW}_{1}-99.4 \mu \mathrm{gNP} \mathrm{g}^{-1} \mathrm{~h}^{-1}$, indicating a lower amount of organic phosphate compounds available in the composting mixture.

The protease activity and protein degradation increased in passive composting due to ammonia losses through aeration. Results for protease activity (Fig. 7g) was recorded highest for summer treatment, $\mathrm{Cs}_{4}\left(916.1 \mu \mathrm{g} \mathrm{h}^{-1}\right)$ at 2 nd week of composting, followed by a gradual and slower decline compared to other enzymes. More interestingly, in $\mathrm{Cs}_{1}$ and $\mathrm{CW}_{1}$ treatments an increase in protease activity was observed even after 8th week $\left(235.6 \mathrm{~g} \mathrm{~h}^{-1}\right)$ and 12th week $\left(94.5 \mathrm{~g} \mathrm{~h}^{-1}\right)$, indicating the requirement of more time for proteins degradation resulting in low stabilization degree. Conversely, Raut et al. [36] reported that ammonia as a product of the protein hydrolytic reactions, can act as an inhibitor and affect protease activity during the composting process.

\subsection{Statistical analysis}

To explore the variables involved in deducing compost maturity through microbial-enzymatic activities with the respective treatments, Two-way ANOVA with replication of variables and Hierarchical Cluster Analysis (HCA) were established. The results reveal significant interactions between the treatments and enzymes, rejecting the null hypothesis, as determined by two-way ANNOVA with $\mathrm{F}_{\text {value }}>\mathrm{F}_{\text {crit }}(P<0.05)$ as given in Table 3.

\subsubsection{Principal component analysis (PCA)}

The results of PCA analysis for various parameters of the derived MSW compost are presented in Fig. 8. The PCA analysis explains the degree of correlation between the components. Based on the PCA results, two principal components ( $\mathrm{F} 1$ and $\mathrm{F} 2$ ) with an eigenvalue -1.0 to 1.0 were extracted, where $\mathrm{F} 1$ and $\mathrm{F} 2$ explain the major conjunctions between the various parameters. The parameters represented far away from the center shows higher correlation, suggestive of more variations in the process. In both the seasons, the F1 corresponds to Temperature, TOC, TN, $\mathrm{C} / \mathrm{N}$ ratio, enzymes depicting degradation in the process, whereas $\mathrm{F} 2$ corresponds to $\mathrm{pH}$ (accelerated process). For summer season, maximum variations for $\mathrm{F} 1$ and $\mathrm{F} 2$ corresponds to $89.52 \%$ and $8.03 \%$ in treatment $\mathrm{Cs}_{4}$, followed by $\mathrm{Cs}_{3}(80.95 \%, 9.19 \%)$ and $\mathrm{Cs}_{2}(78.37,8.18 \%)$. The most significant parameters falling within F1 were Temp, TOC, TN, $\mathrm{C} / \mathrm{N}$ ratio, and enzymes (cell, amy, ure, deh, pro, phos). On the other hand, only $\mathrm{pH}$ was observed causing variations in F2. For winter season, the two principal components, $\mathrm{F} 1$ and $\mathrm{F} 2$, accounts maximum for $80.11 \%$ and $8.11 \%$ in treatment $\mathrm{CW}_{4}$, followed by other treatments $\left(\mathrm{Cw}_{3}, \mathrm{Cw}_{2}\right.$ and control $\left(\mathrm{W}_{1}\right)$. The $\mathrm{F} 1$ component was attributed to a similar pattern as observed in summer set, respectively.

For HCA analysis the dendrogram are illustrated in Fig. 9. There is more similarity between parameters when the Euclidean distances (x-axis) have lower values. In summer treatment $C_{s}$, cellulase, amylase and TN formed a cluster, whereas Temp, TOC, C/N ratio, acidic phosphatase and Dehydrogenase formed another cluster with Alkaline phosphatase, Urease and protease grouping. Similar grouping was observed in dendrogram for the winter treatment set except with lesser similarity between the parameters. In the winter treatment $\left(C_{w}\right)$ two groups were observed: (1) cellulase, amylase, TN and Acidic phosphatase (2) Temperature, TOC, Dehydrogenase, $\mathrm{C} / \mathrm{N}$ ratio and Alkaline phosphatase both clustered with Urease and Protease. All these observations deduce a substantial relation between the environmental and the biological factors that ultimately lead to advancement of maturity during the composting process [7].

\subsubsection{Kinetics study}

For designing an effective composting system, the study of kinetics along with some theoretical considerations is 
Table 3 Correlation coefficients and ANOVA: two factor with replication analysis of the MSW treatment piles among C/N ratio, temperature and enzymatic activity

\begin{tabular}{|c|c|c|c|c|c|c|c|c|c|c|}
\hline & Temp & $\mathrm{C} / \mathrm{N}$ & \multicolumn{2}{|c|}{ Amylase } & Protease & Urease & Cellulase & $\begin{array}{l}\text { Alkaline } \\
\text { phos- } \\
\text { phatase }\end{array}$ & Acidic phosphatase & Dehydrogenase \\
\hline Temp & \multicolumn{2}{|l|}{1.000} & & & & & & & & \\
\hline $\mathrm{C} / \mathrm{N}$ & $0.565 \mathrm{~ns}$ & 1.000 & & & & & & & & \\
\hline Amylase & $-0.932^{* *}$ & $-0.698 n s$ & \multicolumn{2}{|l|}{1.000} & & & & & & \\
\hline Protease & $-0.846^{* *}$ & $-0.732^{*}$ & \multicolumn{2}{|c|}{$0.835^{* *}$} & 1.000 & & & & & \\
\hline Urease & $-0.640 \mathrm{~ns}$ & $-0.969^{* *}$ & \multicolumn{2}{|c|}{$0.717^{*}$} & $0.850^{* *}$ & 1.000 & & & & \\
\hline Cellulase & $-0.707^{*}$ & $-0.794^{*}$ & \multicolumn{2}{|c|}{$0.710^{*}$} & $0.961^{* *}$ & $0.899 * 8$ & 1.000 & & & \\
\hline Alk. Phosphatase & $-0.647 \mathrm{~ns}$ & $-0.770^{*}$ & \multicolumn{2}{|c|}{$0.605 \mathrm{~ns}$} & $0.909^{* *}$ & $0.891^{* *}$ & $0.972^{* *}$ & 1.000 & & \\
\hline Aci. Phosphatase & $-0.766^{*}$ & $-0.665 \mathrm{~ns}$ & \multicolumn{2}{|c|}{$0.824^{* *}$} & $0.843^{* *}$ & $0.709^{*}$ & $0.764^{*}$ & $0.621 \mathrm{~ns}$ & 1.000 & \\
\hline Dehydrogenase & $-0.446 \mathrm{~ns}$ & $-0.827^{*}$ & \multicolumn{2}{|c|}{$0.420 \mathrm{~ns}$} & $0.673 \mathrm{~ns}$ & $0.872^{* *}$ & $0.807^{*}$ & $0.892^{* *}$ & $0.371 \mathrm{~ns}$ & 1.000 \\
\hline \multicolumn{11}{|l|}{ ANOVA } \\
\hline \multicolumn{2}{|l|}{ Source of variation } & \multicolumn{2}{|c|}{$\begin{array}{l}\text { SS (sum-of squares } \\
\text { value) }\end{array}$} & \multicolumn{2}{|c|}{$\begin{array}{l}\text { Df (degree of } \\
\text { freedom) }\end{array}$} & \multicolumn{2}{|l|}{ MS } & F statistic & $P$ value & F critical \\
\hline Sample & \multicolumn{2}{|c|}{7542.922} & \multicolumn{3}{|c|}{1} & \multicolumn{2}{|c|}{7542.922} & 12.82876 & 0.000795 & 4.042652 \\
\hline Columns & \multicolumn{2}{|c|}{$99,238.23$} & \multicolumn{3}{|c|}{7} & \multicolumn{2}{|c|}{$14,176.89$} & 24.1116 & $1.07 \mathrm{E}-13$ & 2.207436 \\
\hline Interaction & \multicolumn{2}{|c|}{$16,108.47$} & \multicolumn{3}{|c|}{7} & \multicolumn{2}{|c|}{2301.21} & \multirow[t]{2}{*}{3.913825} & 0.001888 & 2.207436 \\
\hline Within & \multicolumn{2}{|c|}{$28,222.54$} & & 48 & & 587 & 7.9696 & & & \\
\hline Total & & $1,112.2$ & & 63 & & & & & & \\
\hline
\end{tabular}

${ }^{*}$ Correlation is significant at the 0.05 level (two tailed)

${ }^{* *}$ Correlation is significant at the 0.01 level (two tailed)

(a)
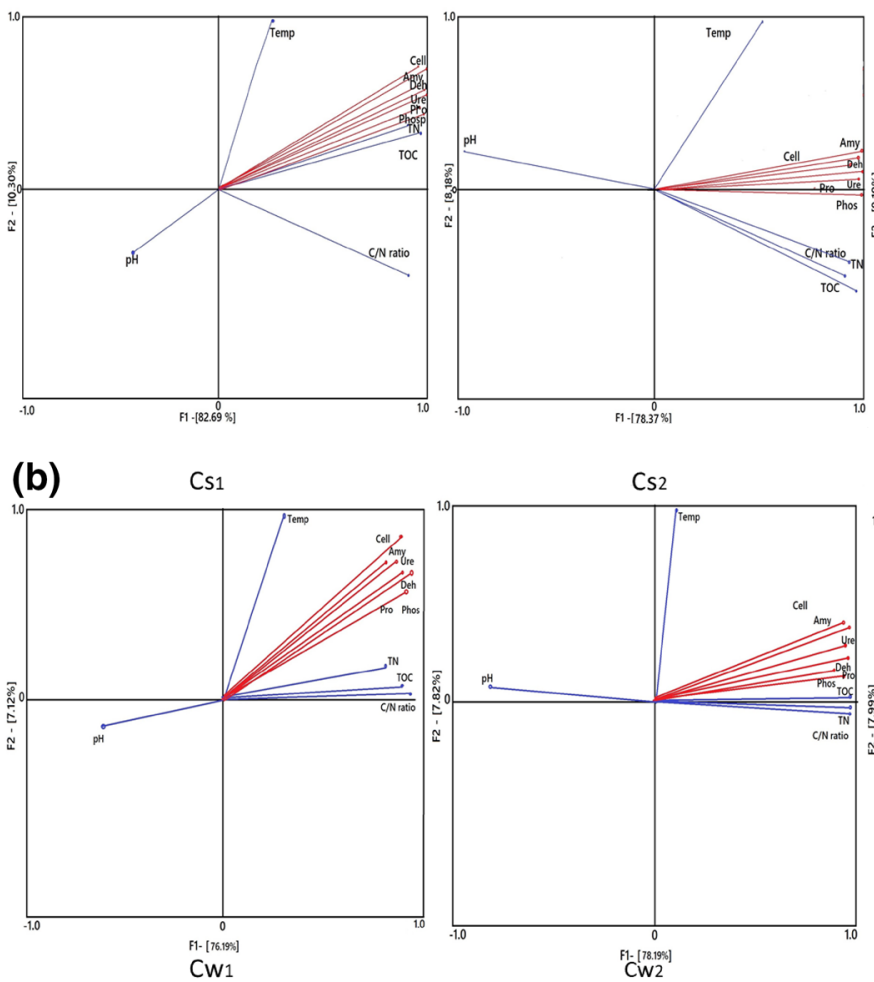

Cs2

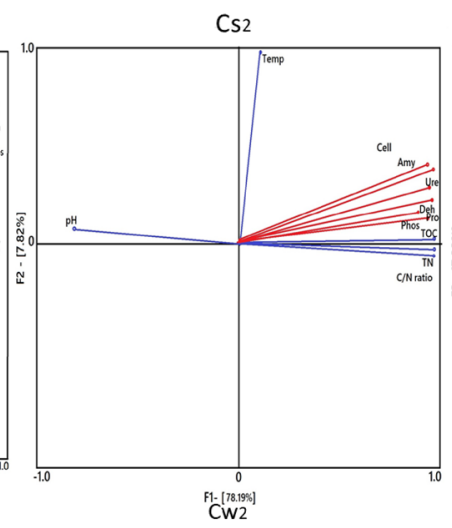

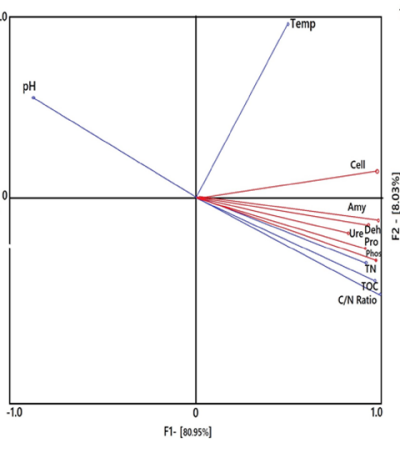

Cs3
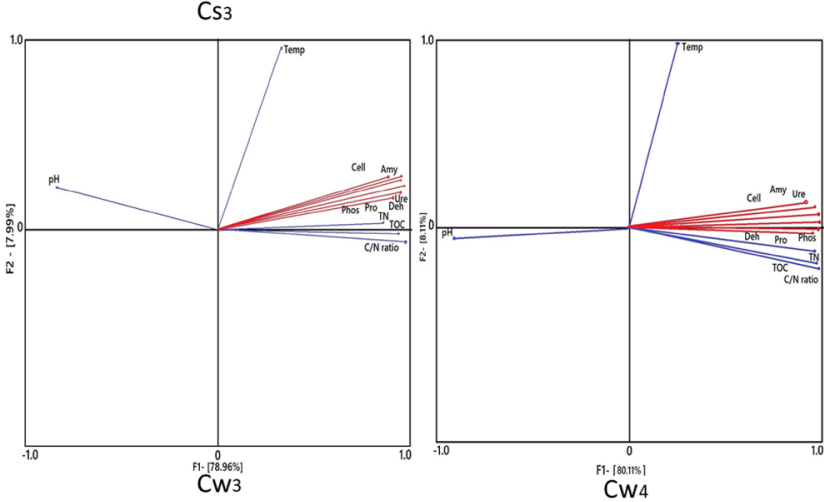

Fig. 8 PCA analysis for a summer, $\mathbf{b}$ winter treatment sets after 90 days of MSW composting 
Fig. 9 Dendrogram of a summer, b winter treatment sets after 90 days of MSW composting

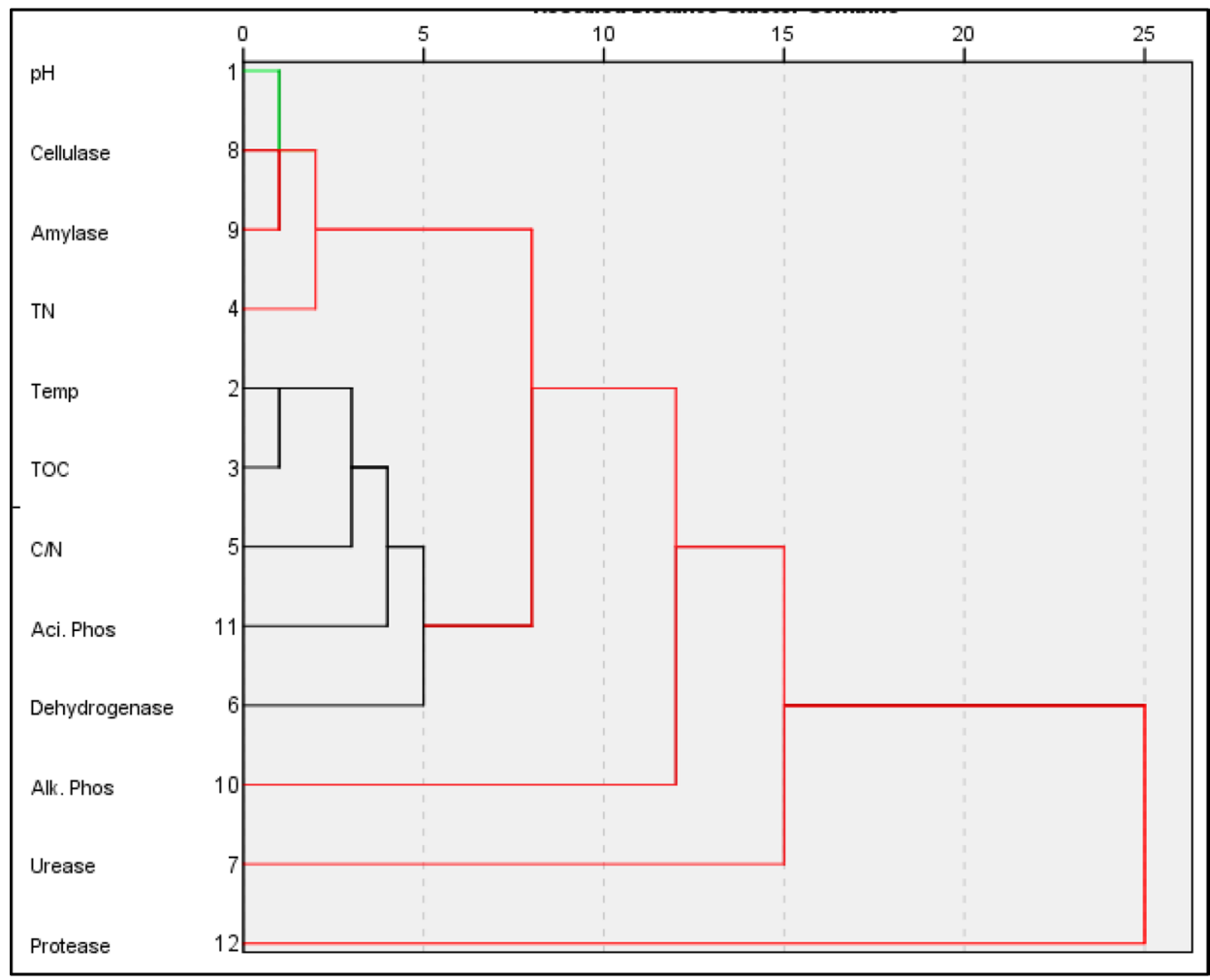

(a) Summer

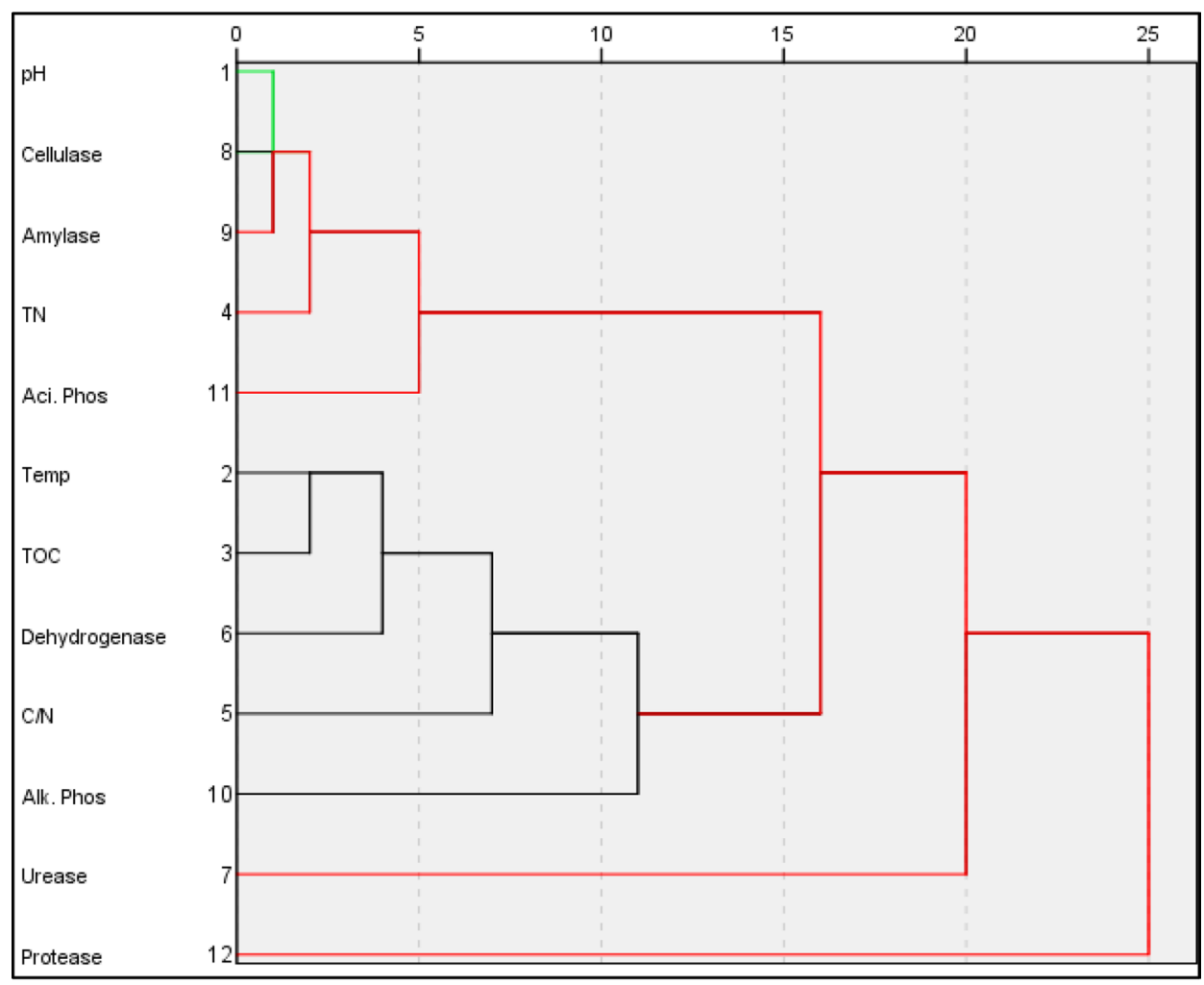

(b) Winter 
an important tool. In this study, few assumptions were applied (1) uniform dispersal of each bacterial suspension to maintain homogeneity (2) Optimization of treatments with suitable organic supplements for microbial growth.

The enzyme kinetic study was undertaken in four steps:

1. Formation of EMOC (Efficient microbial-organic content) complex that disintegrates to generate a byproduct $P$ as a result of endogenous reaction. Where EM is the Inoculum concentration, $\mathrm{OC}$ the organic concentration (\%) and $\mathrm{K}_{\mathrm{a}}, \mathrm{K}_{\mathrm{b}}$ and $\mathrm{K}_{\mathrm{c}}$ are the specific rate of reactions.

$[E M]+[O C] \underset{k_{b}}{\stackrel{k_{a}}{\longrightarrow}}[E M O C] \longrightarrow k_{c}[E M]+[P]$

$\mathrm{k}_{\mathrm{a}}=\mathrm{k}_{\mathrm{b}}+\mathrm{k}_{\mathrm{c}}$ (equilibrium condition)

$[E M O C]=\frac{\left[E_{M C}\right][O C]}{[O C]+\frac{\left(k_{b}+k_{c}\right)}{k_{a}}}$

\section{$E_{M C}$ is the total microbial concentration}

2. Derivation of Michaelis-Menton equation to project the kinetic rate reaction

$\mathrm{K}_{\mathrm{r}}=\frac{\mathrm{k}_{\mathrm{m}}[\mathrm{OC}]}{\mathrm{k}_{\mathrm{d}}+[\mathrm{OC}]}$

$\mathrm{K}_{\mathrm{r}}=$ rate of reaction, $\mathrm{k}_{\mathrm{m}}=$ maximum reaction rate and $\mathrm{k}_{\mathrm{d}}=$ dissociation constant

3. Lineweaver-Burk plot to determine the kinetic parameters that establish the relation between initial reaction rate and the organic load.

$\frac{1}{\mathrm{~K}_{\mathrm{r}}}=\frac{\mathrm{k}_{\mathrm{d}}[\mathrm{OC}]}{\mathrm{k}_{\mathrm{m}}+[\mathrm{OC}]}$

4. Derive Pseudo first order kinetic model equation in accordance with obtained experimental data

$\frac{\mathrm{d}[\mathrm{C}]}{[\mathrm{C}]_{0}}=-\mathrm{k}_{\mathrm{r}} \mathrm{dt}$

$[C]=[C]_{0} \exp ^{-k r t}$

$\ln \frac{[\mathrm{C}]}{[\mathrm{C}]}=-\mathrm{K}_{\mathrm{r}} \mathrm{t}_{0}$

where $\mathrm{C}$ is the biodegradable organic content, $\mathrm{k}$ is the degradation rate constant (day-1) and $t$ is the time (days).

In this sense, the composting of organic ingredients or decomposition of organic matter is regarded as enzymatic-related microbe system [38]. During 90 days of composting, a reduction in the degradable organic matter was observed attributed to the microbial activities, which
Table 4 Computed values for the initial rate of reaction $\left(\mathrm{K}_{\mathrm{r}}\right)$, correlation coefficient $\left(R^{2}\right)$, the kinetic parameters $\mathrm{k}_{\mathrm{d}}$ and $\mathrm{K}_{\mathrm{m}}$ and the organic load (OC) after 90 day of MSW composting

\begin{tabular}{lllrrl}
\hline Treatment & $\mathrm{K}_{\mathrm{r}}$ & $\mathrm{R}^{2}$ & \multicolumn{1}{l}{$\mathrm{k}_{\mathrm{d}}$} & \multicolumn{1}{l}{$\mathrm{k}_{\mathrm{m}}$} & $\mathrm{OC}$ \\
\hline $\mathrm{Cs}_{1}$ & 0.0031 & 0.761 & 12.03 & 78.67 & 21.31 \\
$\mathrm{Cs}_{2}$ & 0.0096 & 0.861 & 41.45 & 30.95 & 44.98 \\
$\mathrm{Cs}_{3}$ & 0.0086 & 0.940 & 48.96 & 22.56 & 38.31 \\
$\mathrm{Cs}_{4}$ & 0.0074 & 0.992 & 99.12 & 1.58 & 27.47 \\
$\mathrm{Cw}_{1}$ & 0.0011 & 0.743 & 2.68 & 138.15 & 17.68 \\
$\mathrm{Cw}_{2}$ & 0.0034 & 0.865 & 14.81 & 90.98 & 33.19 \\
$\mathrm{Cw}_{3}$ & 0.0028 & 0.823 & 8.46 & 89.28 & 29.33 \\
$\mathrm{Cw}_{4}$ & 0.0026 & 0.897 & 21.78 & 58.58 & 25.19 \\
\hline
\end{tabular}

was in agreement with Whang and Meenaghan [39]. The results from enzymatic kinetic study are illustrated in Fig. 8 and Table 4. The treatment bin, $\mathrm{Cs}_{4}$ showed highest biodegradability with a reaction rate constant of 0.0101 day $^{-1}$ in the compost pile owing to the added mixture of microbial inoculum and cow dung slurry. It also evident by the highest temperature $\left(63^{\circ} \mathrm{C}\right)$ attained in the treatment bin $\left(\mathrm{Cs}_{4}\right)$ as a result of microbial respiration during the waste degradation process. This was followed by bin treatment $\mathrm{Cs}_{2}$ and $\mathrm{Cs}_{3}$ with reaction rate constants $\left(\mathrm{k}_{\mathrm{r}}\right)$ of 0.0062 and 0.0059 day $^{-1}$, respectively. In contrast, winter treatment set showed lower biodegradability with reaction rate constant of 0.0054 day $^{-1}$ in bin $\mathrm{CW}_{4}$, followed by $\mathrm{CW}_{3}\left(0.0032\right.$ day $\left.^{-1}\right)$ and $\mathrm{CW}_{2}$, rate constant being $0.0024 \mathrm{day}^{-1}$. While, minimum values for rate constant 0.0011 day $^{-1}$ was observed in control treatment $\left(\mathrm{CW}_{1}\right)$, respectively. This implies that winter treatments had incomplete degradation of substrates with lower biodegradability. For estimation of mathematical models derived by experimental data, correlation coefficient $\left(R^{2}\right)$ has been extensively used [40]. It can be observed that for all summer treatments (except control $\mathrm{Cs}_{1}, 0.761$ ) the degradation process shows the correlation of the exponential function with higher values for coefficient of determination $\left(\mathrm{R}^{2}\right), 0.992\left(\mathrm{Cs}_{4}\right), 0.940\left(\mathrm{Cs}_{3}\right)$, $0.861\left(\mathrm{Cs}_{2}\right)$ for MSW, respectively. The estimated kinetic values fitted well to first order reaction as shown by $\mathrm{R}^{2}$ value ( 0.86-0.96). However, for winter season the values for rate of degradation very low in comparison to summer season.

The slope and intercept of a Lineweaver-Burk plot (1/ $\mathrm{k}_{\mathrm{r}}$ vs. 1/OC) as shown in Fig. 10, graphically determines the kinetic parameters $\mathrm{k}_{d}$ and $\mathrm{K}_{\mathrm{m}}$ (Eq. 5) by correlating the initial rate of reaction $\left(\mathrm{K}_{\mathrm{r}}\right)$ and the organic load $(\mathrm{OC})$, resulting in a linear relationship [39]. The parameter $\mathrm{K}_{\mathrm{m}}$ here represents maximum limiting velocity while $K_{d}$ is the dissociation constant. They depend on process parameters like aeration, temperature, moisture and chemical conditions. In study, MSW treatment $\mathrm{Cs}_{4}$ showed maximum value of 
Fig. 10 Lineweaver-Burk plot for a summer season, $\mathbf{b}$ winter season during 90 days of MSW composting

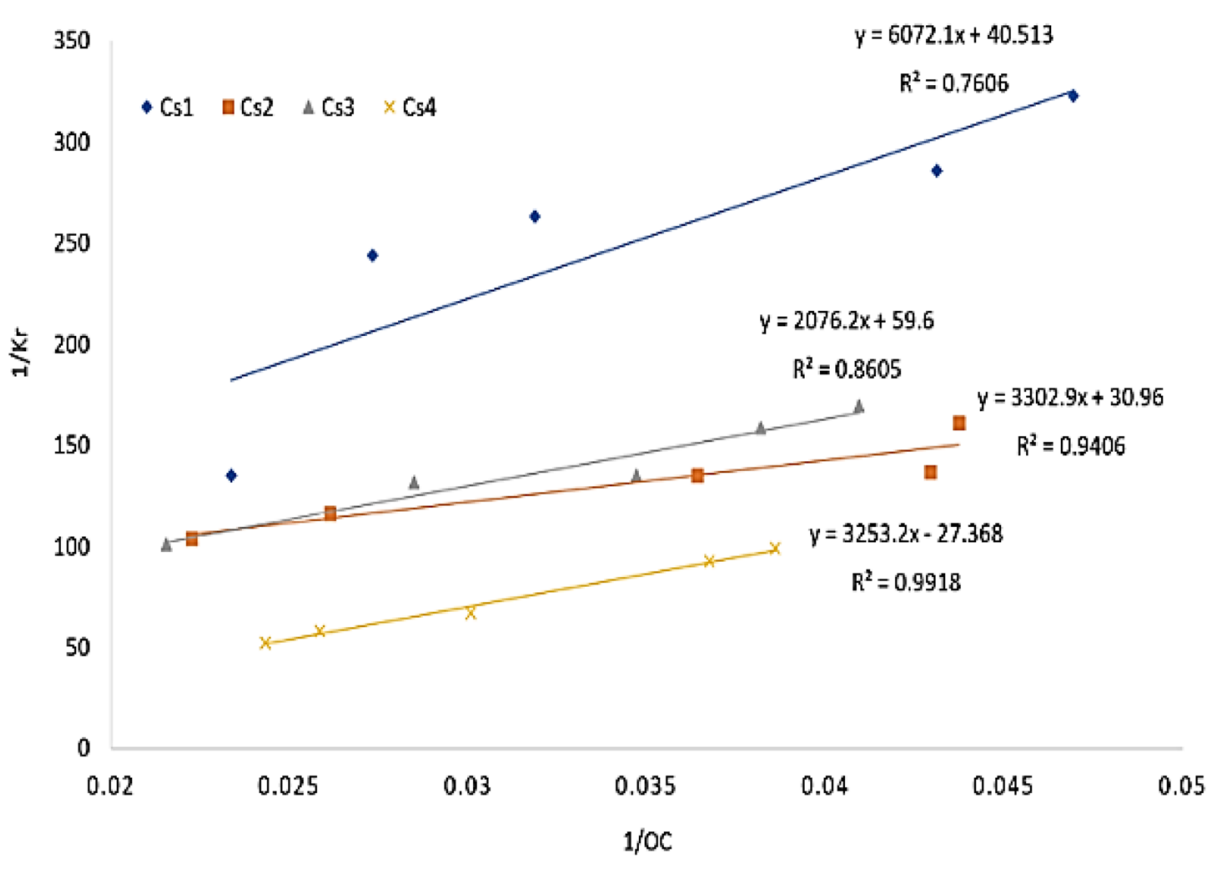

(a) summer season

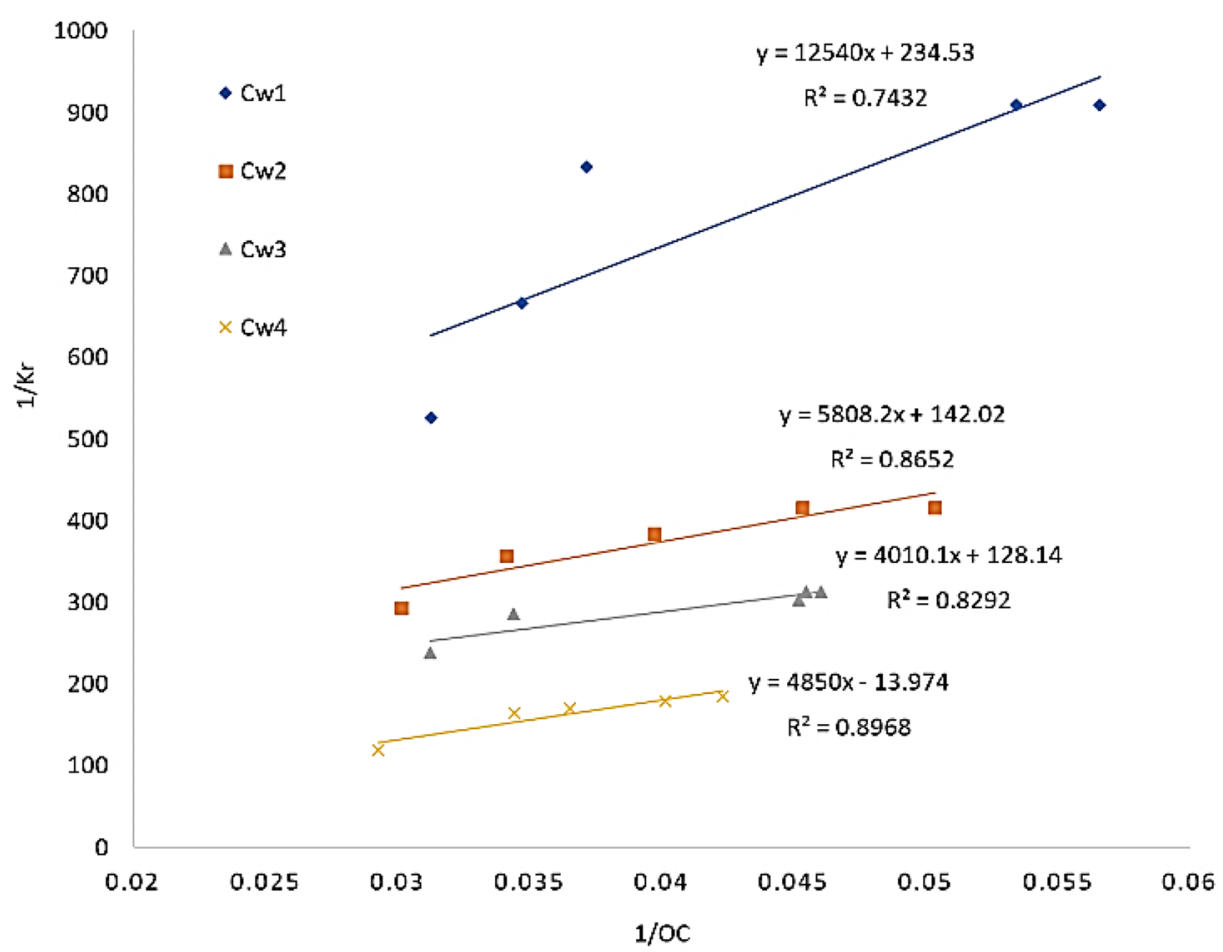

(b) winter season
$\mathrm{K}_{\mathrm{d}}$ (99.12) owing to the fastest rate of organic matter degradation which might be due to the amendments (EM and cow dung slurry). Subsequently, treatment $\mathrm{Cs}_{4}$ shows the least value of $\mathrm{k}_{\mathrm{m}}$ (1.58) compared to other treatments. So, it could be concluded that $100 \%$ raw material acted as feedstock to satisfy the enzyme-substrate affinity. The highest value for $k_{m}$ (138.1) and lowest value for $K_{d}(8.68)$ was observed in treatment $\mathrm{Cw}_{1}$ compared to other treatments. This is ascribed to lower microbial degradation 
efficiency, due to insufficient temperature or nutrients in the waste mixture resulting in microbial deactivation.

\section{Conclusion}

The present study aims at fabricating the importance of microbial-enzyme kinetics in a small-scale composting system. Ambient temperature extensively influenced the physicochemical, microbial and enzymatic properties of the MSW during passive bin composting. MSW degradation followed first-order kinetics during composting with better biodegradability rates for summer season. To conclude summer composting facilitated with inoculum and cow dung slurry will achieve better and more satisfactory sanitization and biodegradation than winter composting generating immature and poor-quality final product.

Acknowledgements Authors are thankful to the University research scholarship scheme of Maharshi Dayanand University, Rohtak (Haryana), India for funding the present research.

\section{Compliance with ethical standards}

Conflict of interest On behalf of all authors, the corresponding author states that there is no conflict of interest.

\section{References}

1. Hannan MA, Al Mamun MA, Hussain A, Basri H, Begum RA (2015) A review on technologies and their usage in solid waste monitoring and management systems: issues and challenges. Waste Manag 43:509-523. https://doi.org/10.1016/j.wasma n.2015.05.033

2. Scheutz C, Pedicone A, Pedersen GB, Kjeldsen P (2011) Evaluation of respiration in compost landfill biocovers intended for methane oxidation. Waste Manag 31(5):895-902. https://doi. org/10.1016/j.wasman.2010.11.019

3. Delgado A, Solera del Rio R, Sales D, Garcia-Morales J (2004) Study of the co-composting process of municipal solid waste and sewage sludge: stability and maturity. In Proceedings of the 11 th conference of the FAO on recycling of agricultural municipal and industrial residues in agriculture, pp 257-260

4. Rastogi M, Nandal M (2018) Composting an emerging technology for solid waste management in India. In: Handbook of research on microbial tools for environmental waste management. https://doi.org/10.4018/978-1-5225-3540-9.ch006

5. Adegunloye DV, Adetuyi FC (2009) Composting of food wastes using cow and pig dung as booster. Afr J Basic Appl Sci 13(3-4):70-75

6. Karak T, Kutu FR, Paul RK, Bora K, Das DK, Khare P, Das K, Dutta AK, Boruah RK (2017) Co-composting of cow dung, municipal solid waste, roadside pond sediment and tannery sludge: role of human hair. Int J Environ Sci Technol 14(3):577-594. https:// doi.org/10.1007/s13762-016-1167-0

7. Li S, Li J, Yuan J, Li G, Zang B, Li Y (2017) The influences of inoculants from municipal sludge and solid waste on compost stability, maturity and enzyme activities during chicken manure composting. Environ Technol 38(13-14):1770-1778. https://doi. org/10.1080/09593330.2017.1291755

8. Sharma A, Sharma R, Arora A, Shah R, Singh A, Pranaw K, Nain $L$ (2014) Insights into rapid composting of paddy straw augmented with efficient microorganism consortium. Int J Recycle Org Waste Agric 3(2):54. https://doi.org/10.1007/s4009 3-014-0054-2

9. Gray KR, Biddlestone AJ, Clark R (1974) Review of composting. Processes and products. Process Biochem 7-12. http://agris.fao. org/agris-search/search.do?recordID=US201302218809

10. Crawford JH (1983) Review of composting. Process Biochem 8:14-15

11. Hamelers HV (2004) Modeling composting kinetics: a review of approaches. Rev Environ Sci Biotechnol 3(4):331-342. https ://doi.org/10.1007/s11157-004-2335-0

12. Cornell Waste Management Institute (1996) Composting. http://cwmi.css.cornell.edu/composting.htm. Accessed 26 Jan 2019

13. Walkley A, Black IA (1934) An examination of the Degtjareff method for determining soil organic matter, and a proposed modification of the chromic acid titration method. Soil Sci 37(1):29-38. https://doi.org/10.1097/00010694-19340 $1000-00003$

14. Singh R, Pradhan K (1981) Determination of nitrogen and protein by Kjeldahl method. Forage Evaluation Science Pvt Publishers Ltd, New Delhi

15. Li X, Zhang R, Pang Y (2008) Characteristics of dairy manure composting with rice straw. Bioresour Technol 99(2):359-367. https://doi.org/10.1016/j.biortech.2006.12.009

16. Casida LE Jr, Klein DA, Santoro T (1964) Soil dehydrogenase activity. Soil Sci 98(6):371-376. https://doi.org/10.1097/00010 694-196412000-00004

17. Wood TM, Bhat KM (1988) Methods for measuring cellulase activities. In: Methods in enzymology. Academic Press, New York, pp 87-112. https://doi.org/10.1016/0076-6879(88)60109-1

18. Fuwa H (1954) A new method for micro determination OCF amylase activity by the use of amylose as the substrate. J Biochem 41(5):583-603. https://doi.org/10.1093/oxfordjournals. jbchem.a126476

19. Folin O, Wu H (1919) A system of blood analysis. J Biol Chem 38(81):116

20. Weatherburn MW (1967) Phenol-hypochlorite reaction for determination of ammonia. Anal Chem 39(8):971-974. https://doi. org/10.1021/ac60252a045

21. Tabatabai MA, Bremner JM (1969) Use of p-nitrophenyl phosphate for assay of soil phosphatase activity. Soil Biol Biochem 1:301-307. https://doi.org/10.1016/0038-0717(69)90012-1

22. Pandey AK, Gaind S, Ali A, Nain L (2009) Effect of bioaugmentation and nitrogen supplementation on composting of paddy straw. Biodegradation 20(3):293-306. https://doi.org/10.1007/ s10532-008-9221-3

23. Guoxue L, Zhang F, Ying Sun JWC, Wong MF (2001) Chemical evaluation of sewage sludge composting as a mature indicator for composting process. Water Air Soil Pollut 132(3-4):333-345. https://doi.org/10.1023/A:1013254815976

24. Singh WR, Pankaj SK, Kalamdhad AS (2015) Reduction of bioavailability and leachability of heavy metals during agitated pile composting of Salvinia natans weed of Loktak lake. Int J Recycle Org Waste Agric 4(2):143-156. https://doi.org/10.1007/ s40093-015-0094-2

25. Edris B, Aminallah Z, Ferdos KM, Nayyereh P, Saeed M, Ali M (2016) Maturity and stability evaluation of composted municipal solid wastes. Health Scope 5(1):1-9. https://doi.org/10.17795/ jhealthscope-33202

26. Tiquia SM, Tam NF, Hodgkiss IJ (1998) Changes in chemical properties during composting of spent pig litter at different 
moisture contents. Agric Ecosyst Environ 67(1):79-89. https:// doi.org/10.1016/S0167-8809(97)00132-1

27. Cabrera F, Martín-Olmedo P, Lopez R, Murillo JM (2005) Nitrogen mineralization in soils amended with composted olive mill sludge. Nutr Cycl Agroecosyst 71(3):249-258. https://doi. org/10.1007/s10705-004-6373-3

28. Fang M, Wong JWC, Ma KK, Wong MH (1999) Co-composting of sewage sludge and coal fly ash: nutrient transformations. Bioresour Technol 67(1):19-24. https://doi.org/10.1016/S0960 -8524(99)00095-4

29. Rebollido RO, Martinez JO, Aguilera YU, Melchor KE, Koerner I, Stegmann RA (2008) Microbial populations during composting process of organic fraction of municipal solid waste. Appl Ecol Environ Res 6(3):61-67

30. Zaccheo P, Ricca G, Crippa L (2002) Organic matter characterization of compost from different feedstock's. Compost Sci Util 10:29-38. https://doi.org/10.1080/1065657X.2002.10702060

31. Sudharsan VV, Kalamdhad AS (2014) Evolution of chemical and biological characterization during thermophilic composting of vegetable waste using rotary drum composter. Int J Environ Sci Technol 12(6):2015-2024. https://doi.org/10.1007/s1376 2-014-0582-3

32. Ling N, Sun Y, Ma J, Guo J, Zhu P, Peng C, Yu G, Ran W, Guo S, Shen $Q$ (2014) Response of the bacterial diversity and soil enzyme activity in particle-size fractions of mollisol after different fertilization in a long-term experiment. Biol Fertil Soils 50(6):901-911. https://doi.org/10.1007/s00374-014-0911-1

33. Rana R, Ganguly R, Gupta AK (2018) Physico-chemical characterization of municipal solid waste from Tricity region of Northern India: a case study. J of Mater Cycles Waste Manag 20(1):678689. https://doi.org/10.1007/s10163-017-0615-3
34. Mobley HLT, Hausinger RP (1989) Microbial ureases: significance, regulation, and molecular characterization. Microbiol Rev 53(1):85-108

35. Castaldi P, Garau G, Melis P (2008) Maturity assessment of compost from municipal solid waste through the study of enzyme activities and water-soluble fractions. Waste Manag 28(3):534540. https://doi.org/10.1016/j.wasman.2007.02.002

36. Raut MP, William SPMP, Bhattacharyya JK, Chakrabarti T, Devotta $S$ (2008) Microbial dynamics and enzyme activities during rapid composting of municipal solid waste-a compost maturity analysis perspective. Bioresour Technol 99(14):6512-6519. https ://doi.org/10.1016/j.biortech.2007.11.030

37. Tejada M, Garcia-Martinez AM, Parrado J (2009) Relationships between biological and chemical parameters on the composting of a municipal solid waste. Bioresour Technol 100(17):40624065. https://doi.org/10.1016/j.biortech.2009.03.034

38. Kumar S, Bhattacharyya JK, Vaidya AN, Chakrabarti T, Devotta S, Akolkar AB (2009) Assessment of the status of municipal solid waste management in metro cities, state capitals, class I cities, and class II towns in India: an insight. Waste Manag 29(2):883895. https://doi.org/10.1016/j.wasman.2008.04.011

39. Whang DS, Meenaghan GF (1980) Kinetic model of composting process. Compost Sci Land Util 21(3):44-46

40. Ebrahimzadeh R, Ghazanfari Moghaddam A, Sarcheshmehpour M, Mortezapour H (2017) A novel kinetic modeling method for the stabilization phase of the composting process for biodegradation of solid wastes. Waste Manag Res 35(12):1226-1236. https://doi.org/10.1177/0734242X17733538

Publisher's Note Springer Nature remains neutral with regard to jurisdictional claims in published maps and institutional affiliations. 